\title{
Assessing the Effects of Fiscal Decentralization on the Education Sector: A Cross-Country Analysis
}

\section{Iftikhar Ahmad}

\begin{abstract}
This paper examines the effects of fiscal decentralization on the education sector for a sample of 62 countries. The results suggest that different sources of fiscal decentralization have distinct effects on education expenditure and quality. While subnational governments that are financed through own-tax revenues are more likely to increase the funds allocated to education, they also seem less concerned with maintaining teaching quality. This study provides evidence that decentralized structures cater better to local social needs. Fiscal decentralization is, therefore, an important policy instrument for achieving social goals.
\end{abstract}

Keywords: Fiscal decentralization, education expenditure, teaching quality, panel data.

JEL classification: H75, H71, H40, H52, I21.

\section{Introduction}

The Millennium Development Goals reflect the need for improved education and health, both of which have a vital impact on the quality of life. Better health and education services ensure greater economic opportunities for individuals while the state benefits simultaneously from better-quality human capital. Given market imperfections and the externalities associated with social spending, public sector involvement is considered mandatory for the provision of basic public goods. However, as human needs increase and public sector resources become more scarce, it becomes important to evaluate the effectiveness of social spending. Higher public spending on health and education by itself is not an effective instrument to remedy imbalances. It is necessary to set proper goals, target the right areas and use scarce resources efficiently to increase the effectiveness of public resource use. In developing countries, poorly managed public spending is a key reason for suboptimal outcomes (World Bank, 2003).

\footnotetext{
* Assistant Professor, Pakistan Institute of Development Economics, Islamabad, Pakistan.
} 
In striving for growth and development, human capital is widely acknowledged as the engine of economic growth. To improve human capital, governments must invest in education and health. Policymakers can do this in two possible ways: either invest more money or look to improve policies. When constrained by resources, policymakers aim to optimize the use of scarce resources. Among the competing social sectors, government spending on health and education is by far the most important. Spending on health and education is argued to enhance economic growth, improve human capital, reduce poverty and achieve better income equality (see Romer, 1986; Lucas, 1988; Barro, 1991; Chu et al., 1995; Tanzi \& Chu, 1998; Baldacci et al., 2008).

In this context, decentralization is critical, given its potential to influence service provision and resource use. Advocates of decentralization argue that it is based on efficient allocation due to better awareness of local needs and preferences. Decentralization is increasingly relevant to the education sector as the demand for learning rises in economies now based predominantly on knowledge and innovation. This has made education the center of attention for decentralization reforms. With the drive toward greater decentralization, policymakers try to ensure better targeting and greater transparency. Local authorities are, therefore, increasingly entrusted with various decentralized tasks, including provision of education services.

The aim of this study is to estimate the effects of fiscal decentralization $^{1}$ on different indicators of education. The literature suggests that taking policymaking closer to the public helps identify and execute what people need most. Galiani, Gertler and Schargrodsky (2008) review the literature on the education decentralization and show a positive association between decentralization and education preferences. Faguet (2004) argues that local governments have more accurate information on people's preferences in education, which leads to positive results. Behrman and King (2001) also note a level of harmonization between household decisions and steps taken in a decentralized structure.

In a study on Argentina, Eskeland and Filmer (2007) find a positive association between school autonomy and student performance. Jimenez and Sawada (1999) show that decentralization has led to greater parental participation in schools' decision making in El Salvador. Similarly, Galiani

\footnotetext{
${ }^{1}$ Fiscal decentralization is currently the most viable form to empirically measure and compare the outcomes of decentralization across countries.
} 
and Schargrodsky (2002) find that decentralization improves overall school performance. In a study using panel data for Swiss cantons, Barankay and Lockwood (2007) show that greater decentralization results in higher educational attainment. Del Granado, Martinez-Vazquez and McNab (2005) find a positive association between fiscal decentralization and education expenditures. Falch and Fischer (2012) conclude that decentralized government spending results in higher test scores. Looking at Chile, Parry (1997) reports that the decentralization of education has enabled the central and local governments to balance their responsibilities better.

Nevertheless, no policy comes without preconditions and thus cannot bear fruit without an enabling environment. Galiani et al. (2008) point out that the positive effects of decentralization depend on preconditions such as the ability to bridge information asymmetries and heterogeneous preferences, increased local participation and greater accountability of service providers to their clients. Therefore, there is the chance that decentralization may not improve social indicators, or even cause them to deteriorate, if local communities have no voice and face elite capture (Bardhan \& Mookherjee, 2005) or if local governments lack the capacity to administer public services efficiently (Smith, 1985). These risks can limit the positive effects of fiscal decentralization and, therefore, rigorous empirical evidence is essential to determine the extent to which it might contribute to the education sector. Appendix 1 summarizes the literature on education indicators and their determinants.

Despite the available literature in this area, there is need for further empirical evidence to quantify the effects of fiscal decentralization on education outcomes (Hanushek, 2002). The available empirical evidence is based largely on country-specific studies that use primary survey or national secondary data sources. Few studies have looked at cross-sectional and panel data for different countries in this context. One reason cited for the limited research is the absence of comparable data across countries. Nevertheless, as better, more consistent datasets are published, it becomes easier to assess the effects of fiscal decentralization on basic education indicators using cross-country data.

Recognizing the need for updated research in this area, using crosscountry evidence, this study seeks to analyze the impact of fiscal decentralization on the education sector, using a rich panel dataset for 62 countries in different regions of the world. It focuses on indicators such as education expenditure, the enrollment rate and the quality of education (with the teacher-pupil ratio as a proxy). The study also disaggregates the 
effects of different sources of subnational revenue to investigate how these influence the effectiveness of local structures.

The paper is organized as follows. Section 2 presents the data and methodology used and discusses the theoretical linkages between education indicators and their determinants, especially the nexus with fiscal decentralization. Section 3 presents the empirical results, followed by a discussion in Section 4. Section 5 concludes the study.

\section{Dataset and Methodology}

This section describes the study's hypotheses, empirical model, dataset and properties and the estimation techniques used.

\subsection{Background}

Governments invest in education because of its long-run social and economic returns. As O'Connor (1973, cited in Devine, 1985) notes, the government bears the cost of education and health to increase productivity in the economy with a better-skilled, more productive labor force. Baldacci et al. (2008) analyze the effects of education on economic growth, showing that the positive association between the two is now well established (see also Barro, 1996a, 1996b; Barro \& Sala-i-Martin, 1995; Levine \& Renelt, 1992; Mankiw, Romer \& Weil, 1992; Sala-i-Martin, 1997). Coulombe, Tremblay and Marchand (2004) report that a literacy score that is 1 percent higher than average is associated with a 1.5 percentage point increase in per capita GDP growth.

There are also social implications attached to this spending. Certain goods and services are allocated through the public sector because they are nondivisible and/or consumed collectively (Musgrave \& Musgrave, 1973). Moreover, the free market does not necessarily lead to an equitable distribution of public and merit goods, given their associated externalities. As a merit good, education shares these properties, making the role of the government very important. From this perspective, fiscal decentralization can play an important role in improving service provision. A decentralized administrative structure makes it easier to accommodate diverse local demands as compared with centralized allocation, which may be based on insufficient information. Decentralization, therefore, results in better allocation of scarce resources. 
Decentralization affects development outcomes through a country's political, fiscal and economic systems (Kalirajan \& Otsuka, 2012). Fiscal decentralization makes policymakers accountable through local elections, which improves transparency. This makes it reasonable to assume that it will have a positive effect on education as well as other social sectors. ${ }^{2}$ Although there is some empirical support for this argument, further research is always desirable. Accordingly, we test the hypothesis that fiscal decentralization improves education indicators. The study's cross-country panel data analysis will help distinguish between the effects of different decentralization policies.

\subsection{Hypotheses}

The study's main hypotheses are discussed below:

- Fiscal decentralization has a positive effect on the education sector. Increased fiscal decentralization helps allocate resources more efficiently and presumably translates public demand into the actions required. The coefficients of the fiscal decentralization measures show whether this effect is significant.

- Different decentralization policies result in distinct outcomes. We analyze the cross-country evidence to gauge whether it is only local resources that matter or if different sources of local revenue result in different outcomes. We examine two measures of fiscal decentralization - subnational tax revenues and federal transfers to subnational governments - to determine if they produce similar results or affect the education sector differently. This comparison will shed light on the effectiveness of different sources of subnational revenue.

These hypotheses not only help examine the effects of fiscal decentralization on education, but also make a clear distinction among the available fiscal decentralization policies, if any. A comparison of the effects of local tax revenues and federal transfers at the subnational level will help compare the impact of local autonomy with that of partial fiscal decentralization (Brueckner, 2009).

\footnotetext{
${ }^{2}$ Provided issues such as regional inequalities, elite capture, leviathan governments and capacity issues are taken care of.
} 


\subsection{Empirical Model}

Unlike the health sector, which has easily comparable outcomes such as infant/child mortality and immunization, the education sector does not have necessarily equivalent measures. There are significant differences across countries in terms of the starting age for school, the duration of primary and secondary schooling and, above all, the quality of education. Nevertheless, by examining the most obvious indicators, it is possible to analyze the link between fiscal decentralization and education.

An obvious choice of indicator is education spending. As a direct input to the sector, it reflects the response of the local government to education in the short run. However, evidence from an input indicator alone is not enough and it is important to analyze how policy affects the output or outcome variable. While school enrollment is a good proxy for output, the data available limits its use. The study sample is dominated by countries that are members of the Organisation for Economic Co-operation and Development (OECD) and are characterized by compulsory education policies. In addition, OECD countries have better social protection schemes that have enabled them to achieve almost universal enrollment, with little variation left for empirical analysis. Accordingly, we use the teacherstudent ratio as a proxy for the quality of education. ${ }^{3}$ Both indicators public education expenditure per student and the teacher-student ratio are measured at primary school level, which provides a basis for further education and offers the highest social rate of return (Psacharopoulos, 1994; World Bank, 1995).

Following the literature on education-related macro-studies, we employ the following control variables: per capita income, government spending, demographics and access to infrastructure. In addition, we include the fiscal decentralization measures to identify their impact on education and investigate whether the effect differs across decentralization policies.

\footnotetext{
${ }^{3}$ It is important to mention here that 'test scores' are regarded as the most obvious measure of the education sector's performance, making the PISA test scores a good indicator of the effects of fiscal decentralization on education outcomes. However, consistent data is available primarily for the OECD countries only and with three-year gaps. For this reason, we do not use this indicator here, where the emphasis is on the effects of fiscal decentralization on education in both OECD and non-OECD countries (OECD, 2013).
} 
To estimate the given relationship, we use the following equations:

$$
\begin{aligned}
(E E / S t)_{i t}= & \alpha_{1 i}+\beta_{11} Y_{i t}+\beta_{12} F D_{j i t}+\beta_{13} G E_{i t}+\beta_{14} \operatorname{Pop}(5 \text { to } 14)_{i t}+ \\
& \beta_{15} \operatorname{Pop}(65+)_{i t}+\beta_{16} U r b_{i t}+\varepsilon_{i t} \\
(T / S t)_{i t}= & \alpha_{2 i}+\beta_{21} F D_{j i t}+\beta_{22}\left(\frac{E E}{S t}\right) / Y_{i t}+\beta_{23} \operatorname{Pop}(5 \text { to } 14)_{i t}+\beta_{24} D_{e p}+ \\
& \beta_{25} U r b_{i t}+\varepsilon_{i t}
\end{aligned}
$$

for country $i$ in period $t$ where $j$ represents the three fiscal decentralization measures. In equation (1), EE/St is public education expenditure per student (at primary level) ${ }^{4}$ while in equation (2), the teacher-student ratio is denoted by $T / S t$.

Although the World Bank provides a more elaborate, internationally comparable measure of education expenditure, that is, the ratio of public education expenditure to GDP per capita $(E E / S t) / Y$, we factor out the latter in equation (1) because GDP per capita is a determinant of education spending itself. ${ }^{5}$ Equation (2), however, employs education expenditure per student as a share of GDP per capita to explain the teacher-student ratio in a cross-country setting. Education quality depends on factors that simultaneously affect education expenditure, thus yielding a recursive model for the second equation. 6 Table 1 defines the variables used and specifies the sources of data. The rationale for including the explanatory variables is given below.

\footnotetext{
${ }^{4}$ The choice of a fixed or random effects model depends on the equation $E\left(F D_{j i t} \eta_{i}\right)=0$.

${ }^{5}$ However, the results presented here remain mostly consistent, even for the ratio of education spending per student to GDP per capita. We exclude GDP per capita from the set of explanatory variables to avoid endogeneity problems: any shock affecting per capita GDP will also affect the dependent variable, which contains the same denominator. This would cause confusion and raise specification issues.

${ }^{6}$ Where expenditure per student/GDP per capita (primary) is instrumented with the same set of explanatory variables as given in equation (1), except GDP per capita.
} 


\section{Table 1: Variables and sources of data}

\begin{tabular}{|c|c|c|}
\hline Variable & & Definition \\
\hline $\begin{array}{l}\text { Expenditure per student, } \\
\text { primary (in real US\$) }\end{array}$ & $\mathrm{EE} / \mathrm{St}$ & $\begin{array}{l}\text { Public education expenditure (current) per } \\
\text { student at primary level, in real US dollars, } \\
\text { base year } 2000\end{array}$ \\
\hline $\begin{array}{l}\text { Expenditure per student, } \\
\text { primary (\% of GDP per } \\
\text { capita) }\end{array}$ & $\left(\frac{\mathrm{EE}}{\mathrm{St}}\right) / \mathrm{Y}$ & $\begin{array}{l}\text { Public education expenditure (current) per } \\
\text { student at primary level, as percentage of GDP } \\
\text { per capita }\end{array}$ \\
\hline $\begin{array}{l}\text { Teacher-student ratio, } \\
\text { primary }\end{array}$ & $\mathrm{T} / \mathrm{St}$ & $\begin{array}{l}\text { Number of teachers available relative to } \\
\text { number of students enrolled (at primary level) }\end{array}$ \\
\hline GDP per capita & Y & GDP per capita, in constant US dollars \\
\hline Government spending & $\mathrm{Ge}$ & $\begin{array}{l}\text { General government expenditures, as } \\
\text { percentage of GDP }\end{array}$ \\
\hline Urbanization & Urb & $\begin{array}{l}\text { Percentage of total population living in urban } \\
\text { areas }\end{array}$ \\
\hline Dependency ratio & Dep & $\begin{array}{l}\text { Ratio of dependents (people younger than } 15 \text { or } \\
\text { older than 64) to the working-age population } \\
\text { (aged 15-64), as proportion of dependents per } \\
100 \text { people of working age }\end{array}$ \\
\hline $\begin{array}{l}\text { Population aged } 65 \text { and } \\
\text { above }\end{array}$ & Pop $(65+)$ & $\begin{array}{l}\text { Percentage of total population aged } 65 \text { and } \\
\text { above }\end{array}$ \\
\hline Population aged 5-14 & $\begin{array}{c}\text { Pop }(5- \\
14)\end{array}$ & Percentage of total population aged 5-14 \\
\hline $\begin{array}{l}\text { Subnational govt. share of } \\
\text { tax revenue }\end{array}$ & Fdtax & $\begin{array}{l}\text { Subnational tax revenues as percentage of total } \\
\text { government tax revenues: (tax rev_SG }+ \text { tax } \\
\text { rev_LG) divided by (tax rev_CG }+ \text { tax rev_SG }+ \\
\text { tax rev_LG) }\end{array}$ \\
\hline $\begin{array}{l}\text { Subnational govt. share of } \\
\text { revenue }\end{array}$ & Fdtpr & $\begin{array}{l}\text { Total subnational revenues as percentage of } \\
\text { total government revenues: (total rev_SG + } \\
\text { total rev_LG - grants from SG to LG) divided } \\
\text { by (total rev_CG + total rev_SG + total rev_LG) }\end{array}$ \\
\hline $\begin{array}{l}\text { Vertical grants as share of } \\
\text { subnational govt. revenue }\end{array}$ & Fdtrans & $\begin{array}{l}\text { Total subnational transfers as percentage of } \\
\text { subnational total revenues: (grants_SG + } \\
\text { grants_LG - grants from SG to LG) divided by } \\
\text { (total rev_SG + total rev_LG) }\end{array}$ \\
\hline
\end{tabular}

Note: CG = central government, $\mathrm{SG}=$ state government, $\mathrm{LG}=$ local government.

The data for these indicators is from the World Development Indicators database, except for the demographic indicators, which were sourced from the Health, Nutrition and Population Statistics database.

- GDP per capita $(Y)$ is used to capture the level of development in a country and is expected to have a positive and significant effect on education expenditure.

- Fiscal decentralization (FD) is the main variable of interest. We expect informed policymaking to result in better resource allocation, with a 
positive effect on education. Three measures are used to proxy fiscal decentralization: ${ }^{7}$ the share of subnational tax revenue, the share of subnational total revenues and vertical grants (see Appendix 2 for a note on the construction of the fiscal decentralization measures and descriptive statistics). These measures will help identify the effect of different sources of subnational government revenues on the performance of the education sector. Different revenue sources are assumed to carry distinct incentives for the local government. We ask whether it is the resources available or the level of empowerment that enhances local government efficiency.

- Government expenditure as a percentage of GDP (GE) also explains current education expenditure per student and captures the effect of the government's spending behavior and preferences on the education sector.

- Pop (5-14) denotes the percentage of the population aged 5-14 and is a proxy for the school-age population. This measure reflects the educational needs of the country, which, if not accurately assessed, put pressure on existing resources. Pop (5-14) is expected to have either an insignificant or negative effect on education spending per student and quality.

- Pop (65+) denotes the percentage of the population aged 65 and above, characterizing the interest group hypothesis proposed by Miller (1996). A higher proportion of the elderly is assumed to divert public spending toward other sectors such as health. Hence, this variable is expected to have a negative effect on education spending.

- Urb represents the level of urbanization, where urban areas are assumed to have access to better infrastructure than rural areas. This is expected to have a positive effect on teaching quality (the teacherstudent ratio). However, the variable's sign with respect to public education spending depends on the facilities available in urban areas. While urbanization can improve enrollment through greater access and higher demand for funding, economies of scale can also result in lower per capita expenditure.

- The dependency ratio (Dep) is used as a proxy for the household's ability to afford schooling for its children. A larger dependent population can result in lower demand for schooling if people cannot afford the cost of education. It can also result in increased dependence

\footnotetext{
${ }^{7}$ This is in line with Stegarescu (2004) and Busemeyer (2007).
} 
on the public sector: households that cannot afford private schooling will rely on public schooling, which can increase the demand for the latter. This variable has important implications for education quality.

\subsection{Data}

Using cross-country panel data is associated with several concerns. Countries tend to vary widely in terms of economic and local government structures as well as response to policy. This can make combining data series problematic. In this case, education indicators and the level and implementation of decentralization vary across the sample. Nevertheless, these concerns are overshadowed by the advantages of panel data, including the greater number of observations, the variation in the data both between countries and within them across time, and the ability to generalize results. Country-specific data makes the results more difficult to generalize. Improved econometric techniques help incorporate crosscountry heterogeneity and obtain reasonable results.

\subsubsection{Data Characteristics and Availability Across Countries}

While many studies have assessed the effect of fiscal decentralization on service provision in the health and education sectors, most of them are country-specific or focus on developed/OECD countries for which better data is available. This plays an important role in sample selection. Generalizing the results obtained is not always straightforward. The World Bank's (2012) fiscal decentralization indicators offer better (although not universal) coverage for the period 1972-2010.8 This provides an opportunity to extend the research in this area and reexamine the evidence.

\subsubsection{Descriptive Statistics}

The new fiscal decentralization dataset provides information for 96 countries, while the data for Pakistan was obtained from national sources. However, given the limited data available on education indicators, the sample was reduced to 78 countries (including Pakistan). This yields an unbalanced dataset, with missing values within the series, primarily for the education indicators (the dependent variable), but also for fiscal decentralization (the variable of interest). Table 2 gives descriptive statistics for the variables used in this study.

\footnotetext{
${ }^{8}$ It is important to note that data availability differs among countries. Even within countries,
} missing observations are in some cases an issue. 
Table 2: Descriptive statistics

\begin{tabular}{|c|c|c|c|c|c|c|}
\hline Variable & & Mean & SD & Min & Max & Observations \\
\hline \multirow{3}{*}{$\begin{array}{l}\text { Subnational govt. share } \\
\text { of tax revenue }\end{array}$} & Overall & 18.03 & 13.86 & 0.16 & 58.74 & $\mathrm{~N}=824$ \\
\hline & Between & & 14.36 & 0.18 & 54.84 & $n=69$ \\
\hline & Within & & 2.82 & 1.00 & 33.36 & T-bar $=11.94$ \\
\hline \multirow{3}{*}{$\begin{array}{l}\text { Vertical grants as share } \\
\text { of subnational govt. } \\
\text { revenue }\end{array}$} & Overall & 44.39 & 20.11 & 1.39 & 92.72 & $\mathrm{~N}=811$ \\
\hline & Between & & 20.73 & 4.04 & 87.51 & $\mathrm{n}=72$ \\
\hline & Within & & 7.96 & 16.76 & 75.96 & T-bar $=11.26$ \\
\hline \multirow{3}{*}{$\begin{array}{l}\text { Subnational govt. share } \\
\text { of revenue }\end{array}$} & Overall & 25.68 & 13.91 & 0.82 & 98.27 & $\mathrm{~N}=746$ \\
\hline & Between & & 15.07 & 0.82 & 68.79 & $n=66$ \\
\hline & Within & & 4.15 & -13.19 & 55.16 & $\mathrm{~T}-\mathrm{bar}=11.30$ \\
\hline \multirow{3}{*}{$\begin{array}{l}\text { Expenditure per } \\
\text { student, primary ( } \% \text { of } \\
\text { GDP per capita) }\end{array}$} & Overall & 18.63 & 8.20 & 0.60 & 61.64 & $\mathrm{~N}=864$ \\
\hline & Between & & 8.29 & 3.51 & 58.48 & $\mathrm{n}=78$ \\
\hline & Within & & 4.75 & -12.09 & 44.89 & $\mathrm{~T}$-bar $=11.08$ \\
\hline \multirow{3}{*}{$\begin{array}{l}\text { Expenditure per } \\
\text { student, primary } \\
\text { (constant } 2000 \text { US\$) }\end{array}$} & Overall & 29.88 & 27.87 & 0.19 & 136.66 & $\mathrm{~N}=862$ \\
\hline & Between & & 23.84 & 0.25 & 88.90 & $\mathrm{n}=77$ \\
\hline & Within & & 10.90 & -44.35 & 86.85 & T-bar $=11.19$ \\
\hline \multirow{3}{*}{$\begin{array}{l}\text { Pupil-teacher ratio, } \\
\text { primary a }\end{array}$} & Overall & 19.70 & 8.71 & 8.68 & 82.80 & $\mathrm{~N}=630$ \\
\hline & Between & & 12.18 & 8.68 & 69.50 & $\mathrm{n}=70$ \\
\hline & Within & & 2.61 & 6.41 & 33.00 & T-bar $=9$ \\
\hline \multirow[t]{3}{*}{ GDP per capita } & Overall & $14,171.7$ & $11,002.8$ & 292.09 & $55,807.4$ & $\mathrm{~N}=864$ \\
\hline & Between & & $10,038.7$ & 340.02 & $40,100.6$ & $\mathrm{n}=78$ \\
\hline & Within & & $4,239.7$ & $1,591.2$ & $40,493.9$ & T-bar $=11.08$ \\
\hline \multirow{3}{*}{$\begin{array}{l}\text { Government spending } \\
(\% \text { of GDP) }\end{array}$} & Overall & 18.72 & 5.49 & 4.71 & 43.41 & $\mathrm{~N}=862$ \\
\hline & Between & & 5.28 & 4.71 & 36.34 & $\mathrm{n}=78$ \\
\hline & Within & & 2.18 & 10.10 & 30.32 & T-bar $=11.05$ \\
\hline \multirow[t]{3}{*}{ Population aged 5-14 } & Overall & 15.55 & 4.68 & 8.77 & 29.63 & $\mathrm{~N}=864$ \\
\hline & Between & & 5.91 & 9.23 & 29.23 & $\mathrm{n}=78$ \\
\hline & Within & & 1.83 & 8.05 & 21.12 & T-bar $=11.08$ \\
\hline \multirow[t]{3}{*}{ Population aged $65+$} & Overall & 11.88 & 4.37 & 2.51 & 22.69 & $\mathrm{~N}=864$ \\
\hline & Between & & 5.07 & 2.52 & 21.06 & $\mathrm{n}=78$ \\
\hline & Within & & 1.08 & 7.31 & 15.62 & T-bar $=11.08$ \\
\hline \multirow[t]{3}{*}{ Urbanization (\%) } & Overall & 69.01 & 17.12 & 13.01 & 97.39 & $\mathrm{~N}=864$ \\
\hline & Between & & 18.73 & 14.06 & 96.27 & $\mathrm{n}=78$ \\
\hline & Within & & 2.65 & 56.97 & 79.63 & T-bar $=11.08$ \\
\hline \multirow[t]{3}{*}{ Dependency ratio (\%) } & Overall & 54.57 & 10.88 & 37.53 & 105.52 & $\mathrm{~N}=864$ \\
\hline & Between & & 15.44 & 38.90 & 104.79 & $\mathrm{n}=78$ \\
\hline & Within & & 4.70 & 34.66 & 81.55 & T-bar $=11.08$ \\
\hline
\end{tabular}

Note: $\mathrm{a}=$ represented in reverse order for a better understanding of the term.

Source: Author's calculations. 
On average, subnational governments generate 18 percent of the total tax revenues, but this varies across countries, as indicated by the standard deviation and the range of values (from 0.16 to 58.74 percent). Similarly, within-country variations are given in the third row for each variable (2.82 percent in the case of the subnational share of taxes). These differences are smaller than for the cross-country data. Countries that have implemented deeper reforms register values ranging from 1 to 33.36 percent for the subnational share of taxes variable.

The low share of taxes generated means that subnational units remain dependent on vertical transfers from the central government (44 percent, on average). The ratio of expenditure per primary student to GDP stands at 18.6 percent, on average, with large variations (0.60 to 61.64 percent) across countries. The pupil-teacher ratio indicates that, on average, there is one teacher for every 19 students at primary level, but with large disparities across the sample. This applies to the other variables as well, but the differences in data availability imply that the two dependent variables will not correspond to the same observations.

\section{Empirical Quantification}

While such a wide-ranging dataset provides better coverage across countries and time, allowing more accurate comparisons between different economic blocs, it can also yield unbalanced panels, missing observations, nonstationarity in long panels and persistent differences in countries' level of development, governance, endowments, infrastructure and public preferences. Nonetheless, panel data is valuable when carrying out policy analyses because it accounts for unobserved individual country effects, which a cross-sectional analysis cannot do (Islam, 1995). Moreover, the results of country-specific studies cannot be generalized, making panel studies preferable.

Panels containing long data are more likely to exhibit serial correlation within the error term. Most researchers use a five-year average to resolve this issue and avoid short-run fluctuations in the data, but this is not suited to unbalanced panel data characterized by incomplete coverage. Since our results confirm the existence of serial correlation within the error terms and the panel heteroskedasticity test reveals that the errors do not have a constant variance, we need an estimation technique that takes both autocorrelation as well as heteroskedasticity into account. 
The Hausman specification test is applied to both equations to determine whether to use a fixed effects (FE) or random effects (RE) model for estimation. The evidence suggests that an RE model will generate more efficient and consistent results. We need an estimation technique capable of handling serial correction and RE for heterogeneous countries as well as yielding better results with unbalanced panel data containing missing observations. The most appropriate panel data method in this case is that of Baltagi and $\mathrm{Wu}$ (1999), programmed in Stata as xtregar. This method is suited to panel data models in which the disturbance term is first-order autoregressive. It also provides results for both FE within the estimator and the generalized least squares (GLS) estimator for an RE model.

As a robustness check, we use the GLS estimator (programmed as $x t g l s$ in Stata), which also accounts for panel heteroskedasticity and panelspecific error autocorrelation. The only issue $x \mathrm{tgls}$ does not resolve is that of missing observations when calculating the error autocorrelation. We therefore estimate ${ }^{9}$ equation (1) following Baltagi and $\mathrm{Wu}$ (1999) and report both the FE and RE results along with those for $x t g l s$. However, as equation (2) contains an endogenous variable (education expenditure), we apply two instrumental variable (IV) methods instead.

The first is the two-stage least squares (2SLS) estimation technique in which the endogenous variable is instrumented with the same set of explanatory variables as in equation (1), except for GDP per capita. Second, to solve the endogeneity problem inherent in panel data, we instrument education expenditure with its own lagged value, which is assumed to be independent of contemporaneous errors. Finally, countries with only one observation are dropped such that the number of data points ranges from 2 to 36 for different countries. All the variables used in the estimation are expressed in $\log$ form so that their coefficients represent elasticities.

\section{Results and Discussion}

The empirical results of the analysis are presented in Tables 3 to 9 . Overall, our results are as expected. In addition to the evidence from the Hausman test, the FE and RE estimates lie close together and justify the use of an RE model. The Baltagi and Wu (1999) and 2SLS results are discussed in more detail as the baseline estimates, while the GLS estimates provide a robustness check for both equations. The results

\footnotetext{
${ }^{9}$ Since the public spending equation is dynamic, the GMM technique was also considered for carrying out the estimations. However, the unequally spaced unbalanced panel data with gaps barred the analysis.
} 
remain generally consistent across different estimation techniques, which suggest they are robust.

\subsection{Education Expenditure Outcomes}

Tables 3 to 5 report the empirical results for education expenditure across the overall sample as well as for its decomposition into OECD and non-OECD countries. The effects of fiscal decentralization are captured by three measures: subnational tax revenues, subnational total revenues and federal transfers to the provinces. The empirical evidence confirms that different fiscal decentralization structures have different implications. Table 3 shows that a rise in subnational tax revenues increases education spending per student, with a positive and significant impact. We obtain comparable and consistent results across different estimation techniques. This finding holds for the overall sample as well as for the OECD countries.

The baseline regression suggests that a 1 percent increase in subnational tax revenues increases per pupil education spending by 0.08 percent for the overall sample (62 countries). This coefficient is almost double in the case of the OECD countries where a 1 percent increase in subnational tax revenues leads to a 0.16 percent increase in per pupil government spending. However, the subnational tax revenues variable is not significant for the non-OECD countries, despite its positive sign.

The second measure of fiscal decentralization, subnational total revenues, generates similar results (Table 3), which suggest that an increase in total resources at the local level has a positive effect on education expenditure per pupil. The baseline regression results show that a 1 percentage point increase in total revenues at the subnational level leads to a 0.08 percent increase in per pupil education spending for the overall sample. The corresponding change for the OECD countries is 0.22 percent.

Despite their positive signs, there is no evidence that the coefficients are significantly different from 0 in the case of the non-OECD countries. This suggests that local governments in non-OECD countries lack either the capacity or funds to make effective decisions concerning education spending. This also relates to effective governance, although we have no empirical evidence (due to data limitations) to prove it. Once again, the results suggest that any increase in local revenues does not translate into higher education spending per student in non-OECD countries. 
The third measure, federal transfers to the subnational government, yields a negative relationship between fiscal decentralization and education spending per pupil (Tables 4 and 5). The results are insignificant in the baseline regression and federal transfers have a significant, albeit weak, coefficient only in the GLS estimation for all three samples. This is not unexpected. Federal transfers to lower tiers of government indicate a vertical imbalance: when local governments depend on federal transfers, these may come with strings attached. Here, federal transfers reflect a partially decentralized structure where the central government collects revenues, which subnational governments are responsible for spending. Transfers from the center may or may not be allocated to the social sectors if they are not sector-specific. 


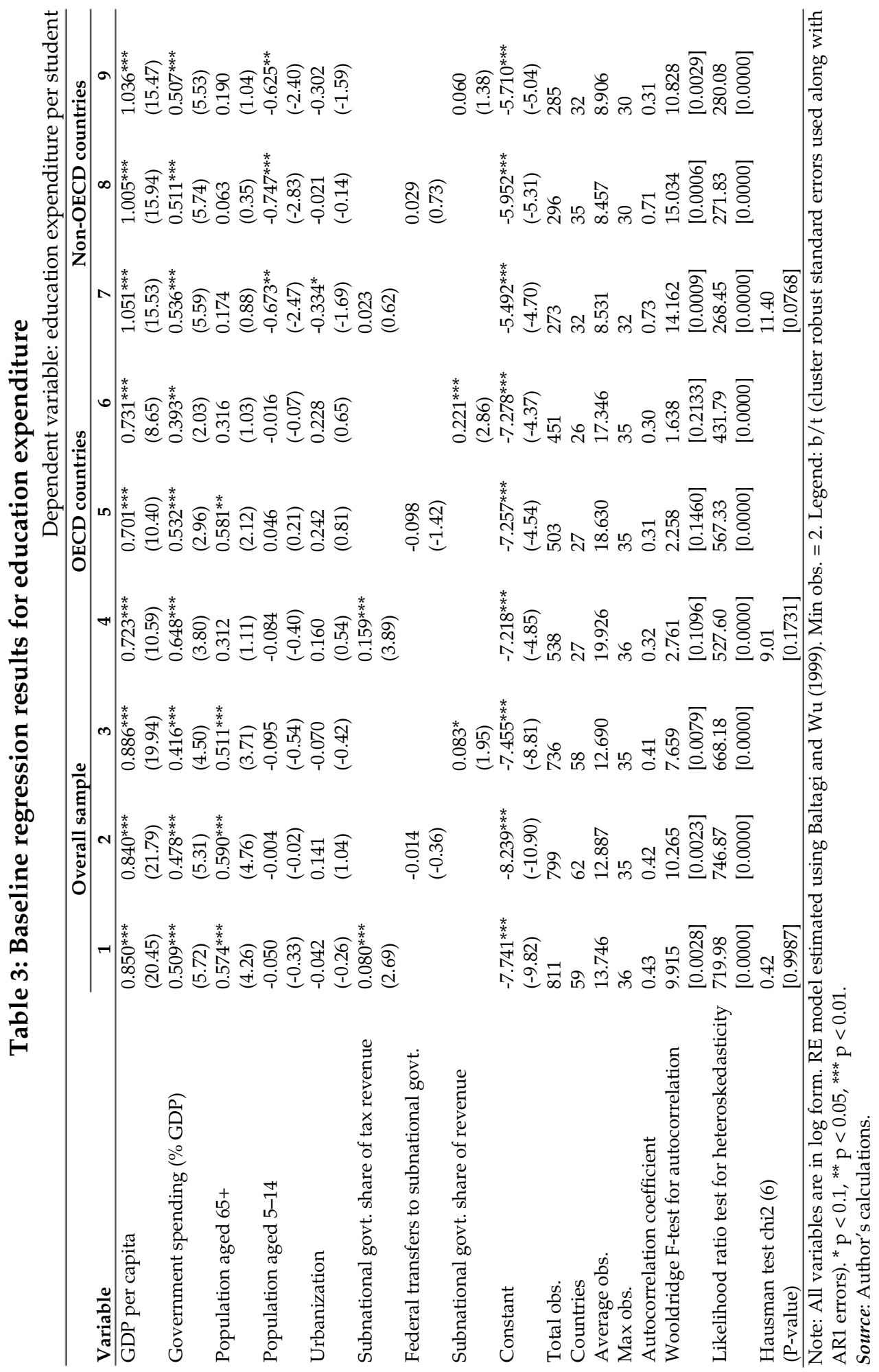



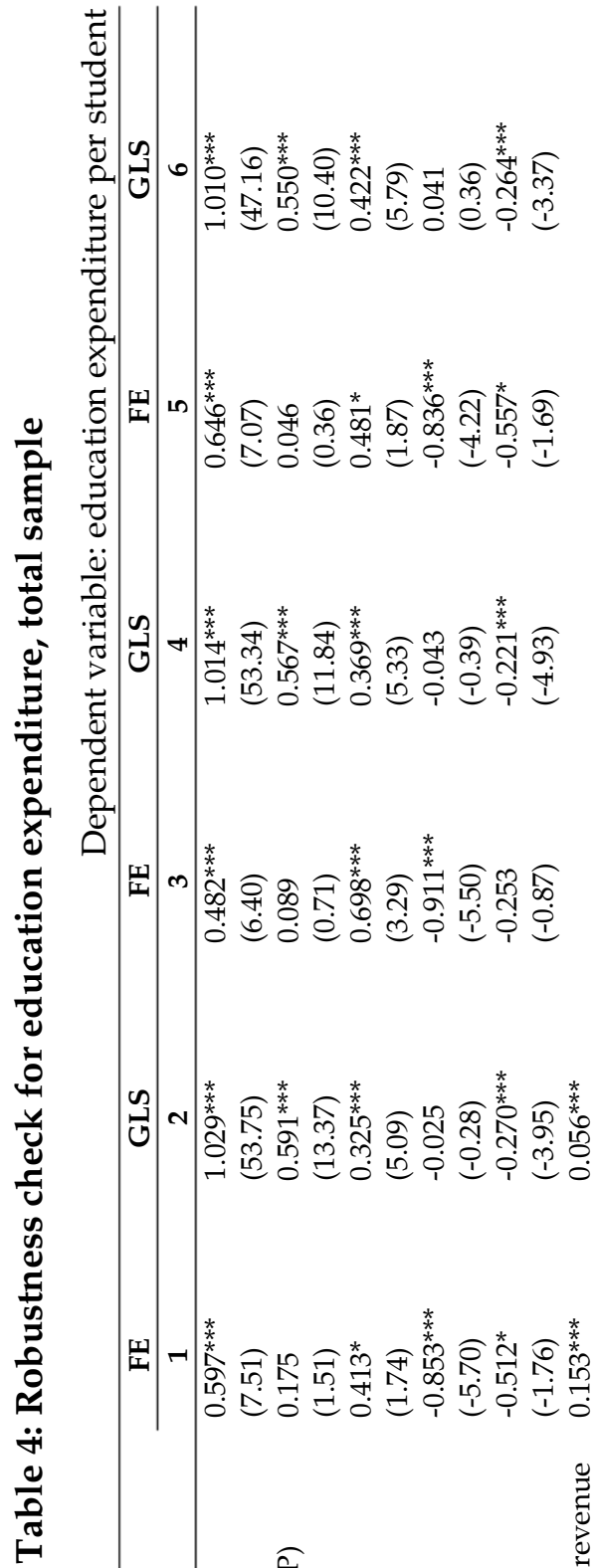

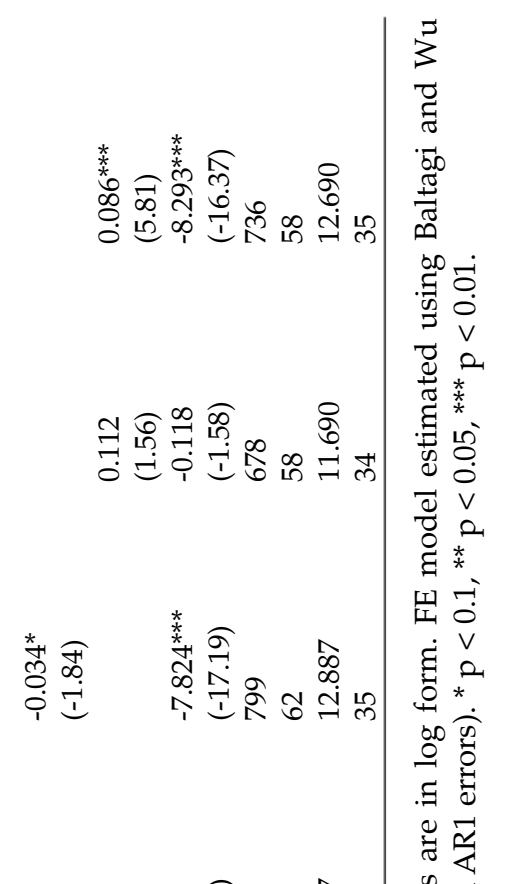

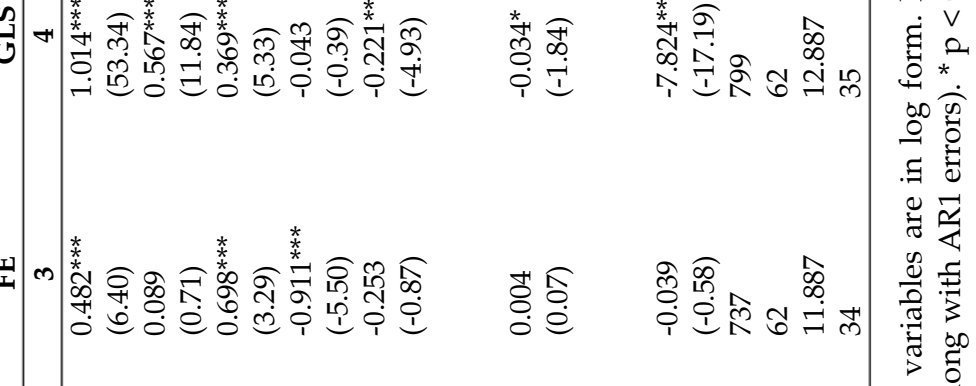

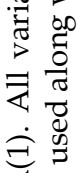

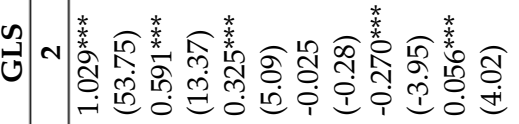

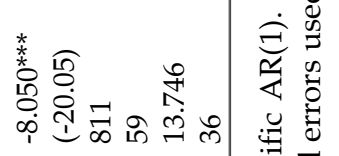

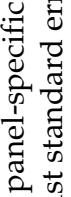

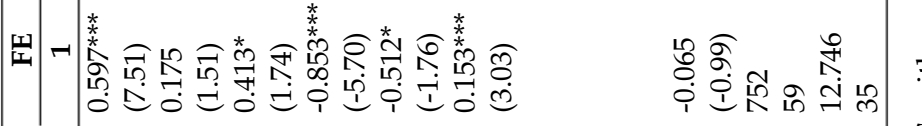
乎

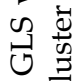

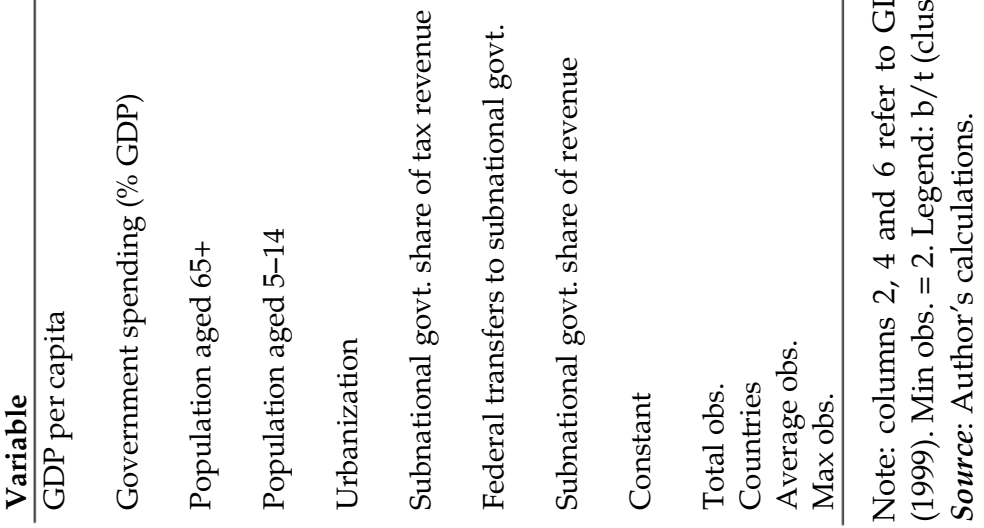




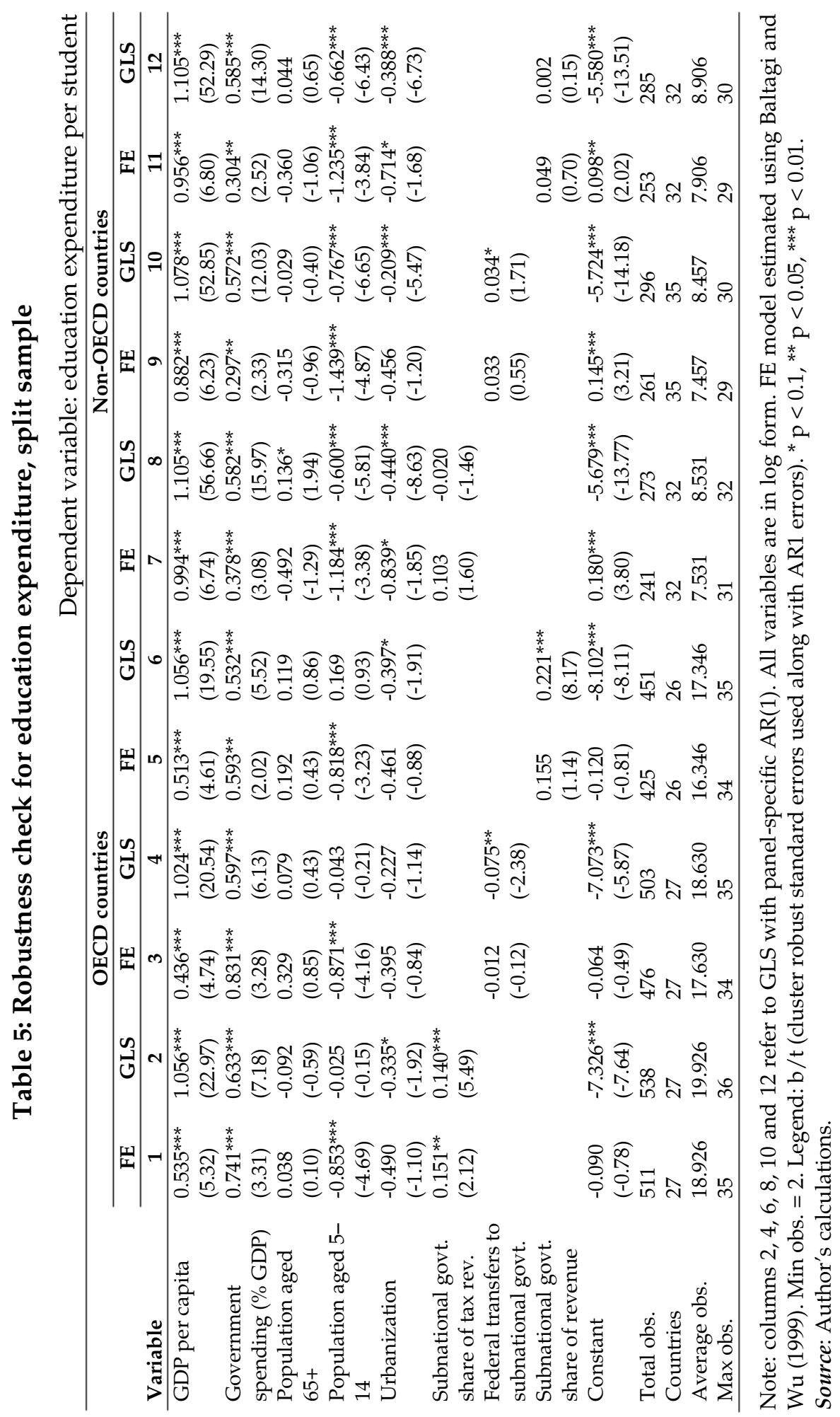


The results are similar across the overall sample and OECD countries, where dependence on federal transfers produces a negative coefficient for education expenditure per pupil. In the case of non-OECD countries, the variable has a positive coefficient, indicating that subnational governments have fewer resources of their own. This supports the earlier argument that subnational governments lack the appropriate resources to improve their spending on the social sectors. The GLS results show that a 1 percent increase in federal transfers to the subnational government improves per student education expenditure by 0.03 percent in non-OECD countries. These results support the hypothesis that different fiscal decentralization policies have different effects for local governments.

Per capita GDP has a consistently positive and significant effect in all three datasets and across the different models containing the three fiscal decentralization proxies. An increase in GDP has a greater impact on education spending in non-OECD countries than in the OECD countries. Similarly, government expenditure has a positive and significant impact on per pupil education spending. The variable captures the government's commitment to education in that an increase in general expenditures does not lower education spending.

The results for the proportion of the population aged 65 and above are not consistent across models. We find no significant evidence supporting the interest group hypothesis. The coefficient remains positive, although primarily for the overall sample because the results are not robust across the different subsets of data. In the case of the decomposed samples of OECD and non-OECD countries, this proxy is not significant except in one instance in each sample.

The school-age population (5-14) variable is a key determinant of education spending because it affects the expenditure needed per student. The results for the OECD countries show that the variable is statistically insignificant in all three models. This suggests that governments in OECD countries are well equipped to cater to their countries' future education needs. Since the overall sample is dominated by OECD countries in terms of data points, the former yields similar results.

This is not the case for the non-OECD sample, where an increase in the proportion of the school-age population has a negative effect on per pupil education spending. This points to inadequate policymaking and poor governance, but might also indicate scarce resources and a high birth rate (the latter increasing the proportion of the school-age population). In 
addition, with a significant number of children out of school, any drive to increase enrollment can have a potentially negative effect on the available resources, particularly in non-OECD countries.

Finally, urbanization tends to reduce the per pupil public education spending needed, which suggests that government spending per student is higher in rural areas than in urban areas where governments enjoy economies of scale. Although the variable's significance is not universal, it yields comparable coefficients wherever significant.

\subsection{Education Outcomes for Teacher-Student Ratio}

Since education quality is represented by the ratio of teachers to students at the primary level, it can be affected by changes in both the numerator and denominator. However, it is reasonable to assume that any shift in resources or policymaking from the center to the lower tiers will not reduce the number of available teachers, especially in non-OECD countries where the teacher-student ratio is comparatively low as it is. Thus, the major impetus for change in this ratio will be any variation in student enrollment. The results should reflect the government's ability to provide newly enrolled students with the required number of teachers to avoid reducing the teacher-student ratio.

Since this ratio is equal to the number of teachers divided by the number of students at the primary level, a higher numerical value for the series indicates the greater availability of teachers per student. It is not easy to explain a positive or negative effect because the latter might still reflect an increase in enrollment (as the positive output of a policy reform). However, if this rise in enrollment is not matched by the required number of teachers, the quality of teaching will fall. A positive coefficient suggests a larger number of teachers per student, reflecting an improvement in teaching quality.

As with the education expenditure equation, we use the same three fiscal decentralization indicators and three different subsets of data to gauge education quality. Table 6 presents the 2SLS results for the teacherstudent ratio equation. As discussed earlier, education expenditure per pupil and education quality are influenced by nearly the same set of independent variables and, therefore, the 2SLS and IV methods are used to resolve the endogeneity problem. 
In the 2SLS estimation, education expenditure is now presented as a relatively more comprehensive measure: per pupil education spending as a share of per capita GDP. We assume a similar set of explanatory variables apart from GDP per capita and the proportion of the population aged 65 and above. The latter is dropped because the earlier results were not robust. Again, the Hausman specification test suggests that an RE model be used. In addition to the 2SLS baseline regression with RE, the GLS estimator ${ }^{10}$ is used in the IV approach where per pupil education expenditure (as a ratio to per capita GDP) is lagged by one and two years to avoid an endogeneity problem. Tables 7 to 9 present the results for the GLS estimation and 2SLS FE results. The results are largely comparable across the two estimation techniques and appear to be robust.

The results in Table 6 suggest that an increase in subnational tax revenues has a negative and significant effect on the dependent variable, which means that greater local autonomy increases the number of students per teacher. For the overall sample, a 1 percent increase in subnational tax revenues leads to a -0.03 percentage point change in the number of teachers per student. Despite having the lowest coefficient of all the significant variables, this is a disappointing result because it implies that local autonomy is associated with lower education quality. It can also be interpreted to mean that local governments are more likely to focus on improving enrollment than on maintaining or improving the quality of education by providing the appropriate number of teachers. This result is consistent across the overall sample and non-OECD countries.

As expected, the coefficient of subnational tax revenues is insignificant for the OECD countries. Given their level of development, they are able to plan and execute long-run education policies successfully and, therefore, any transition from central to local governments has no significant effect on education quality. In addition, with a near 100 percent enrollment rate, they are better able to assess and finance their future education needs. This does not hold for the non-OECD countries and drives the result for the overall sample.

${ }^{10}$ Taking care of heteroskedasticity and panel-specific AR1 using panel-corrected standard errors. 


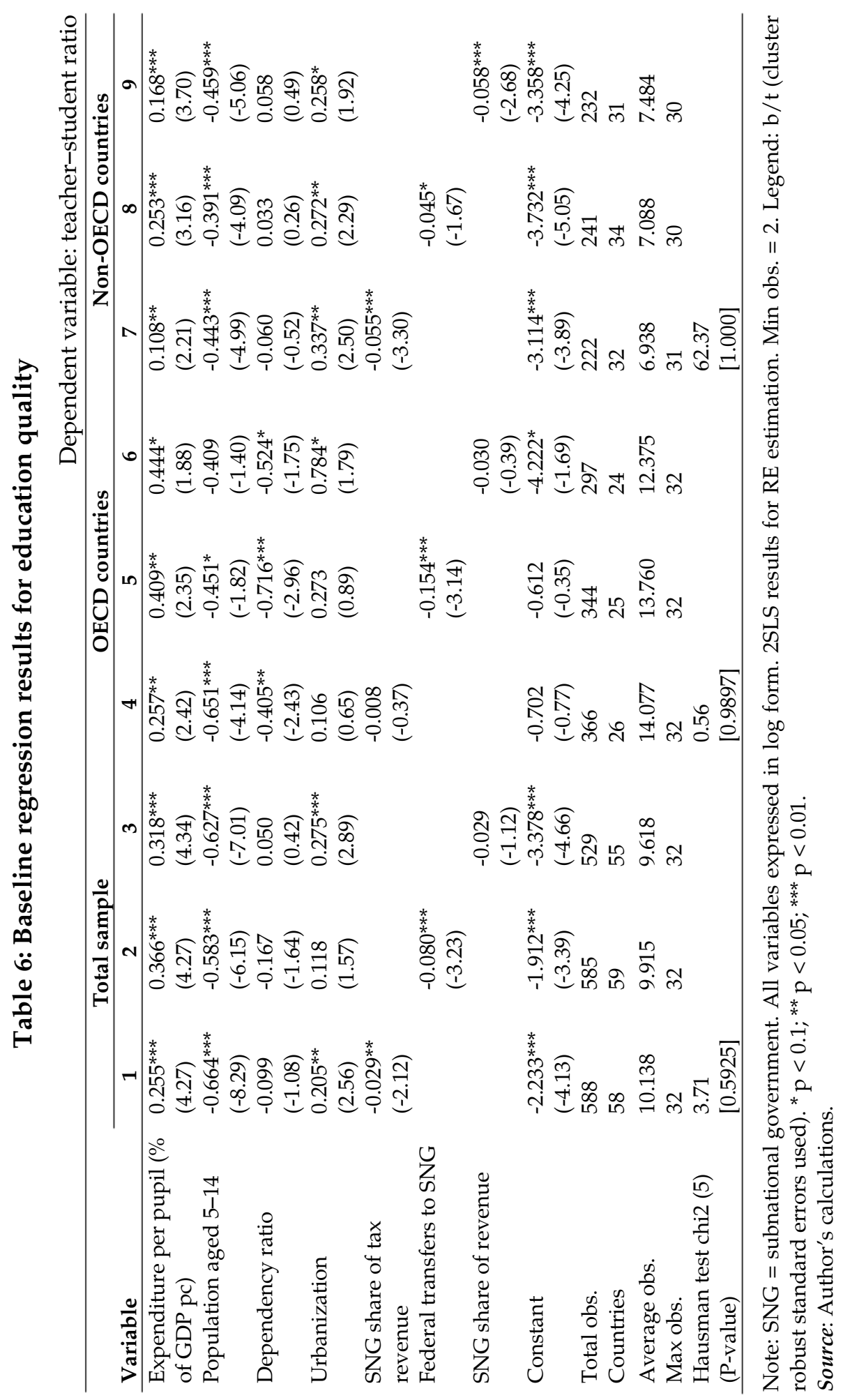




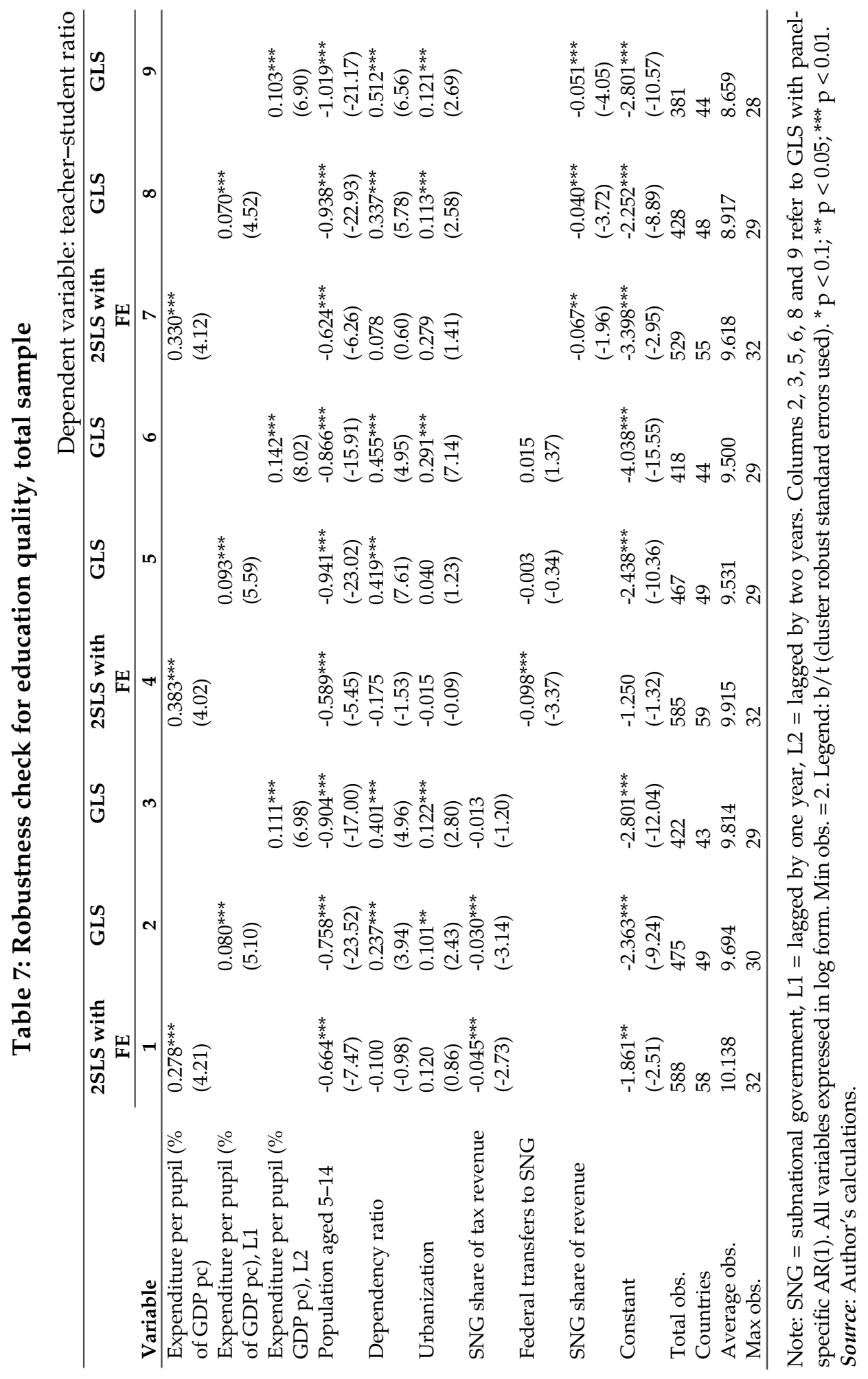




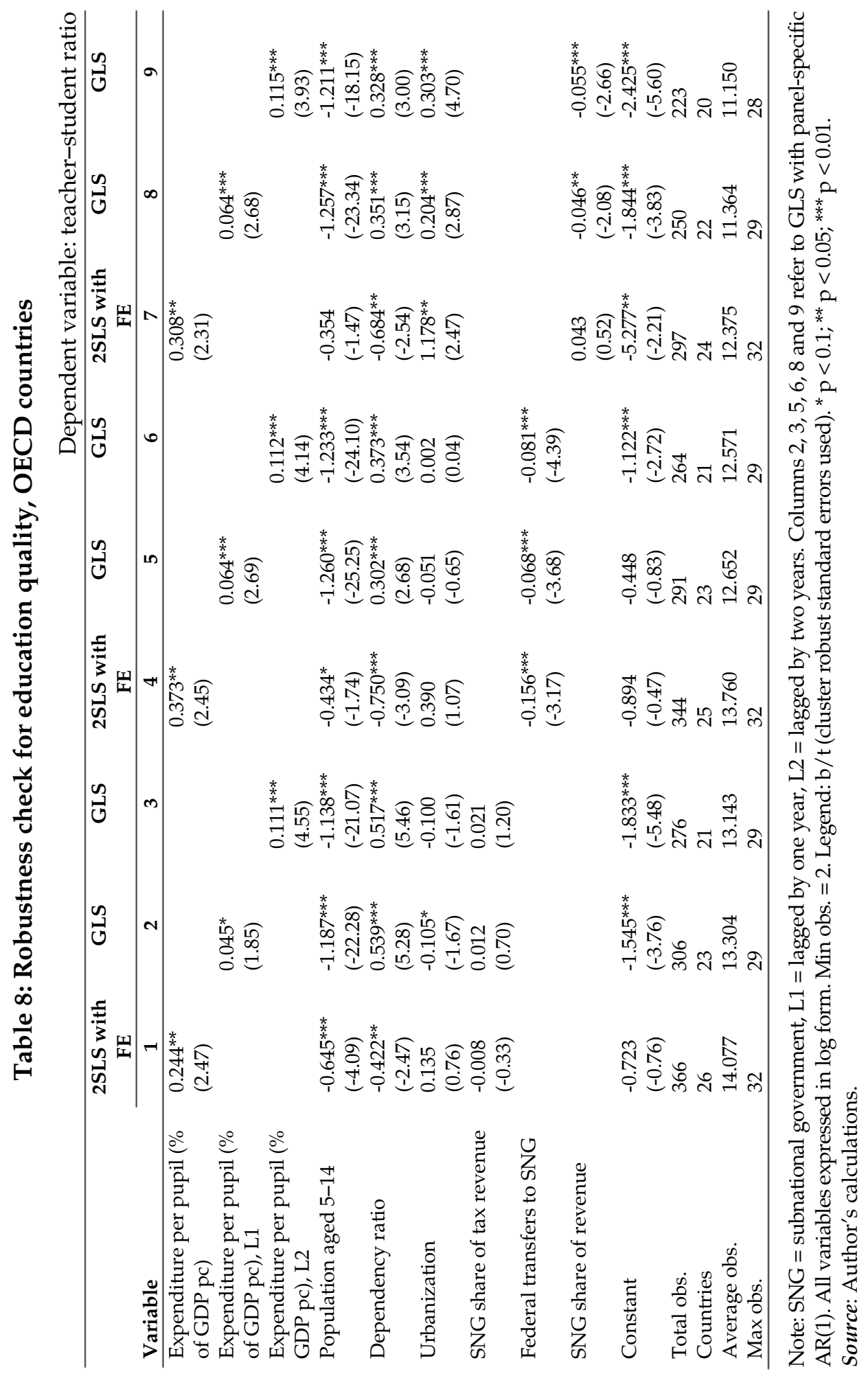




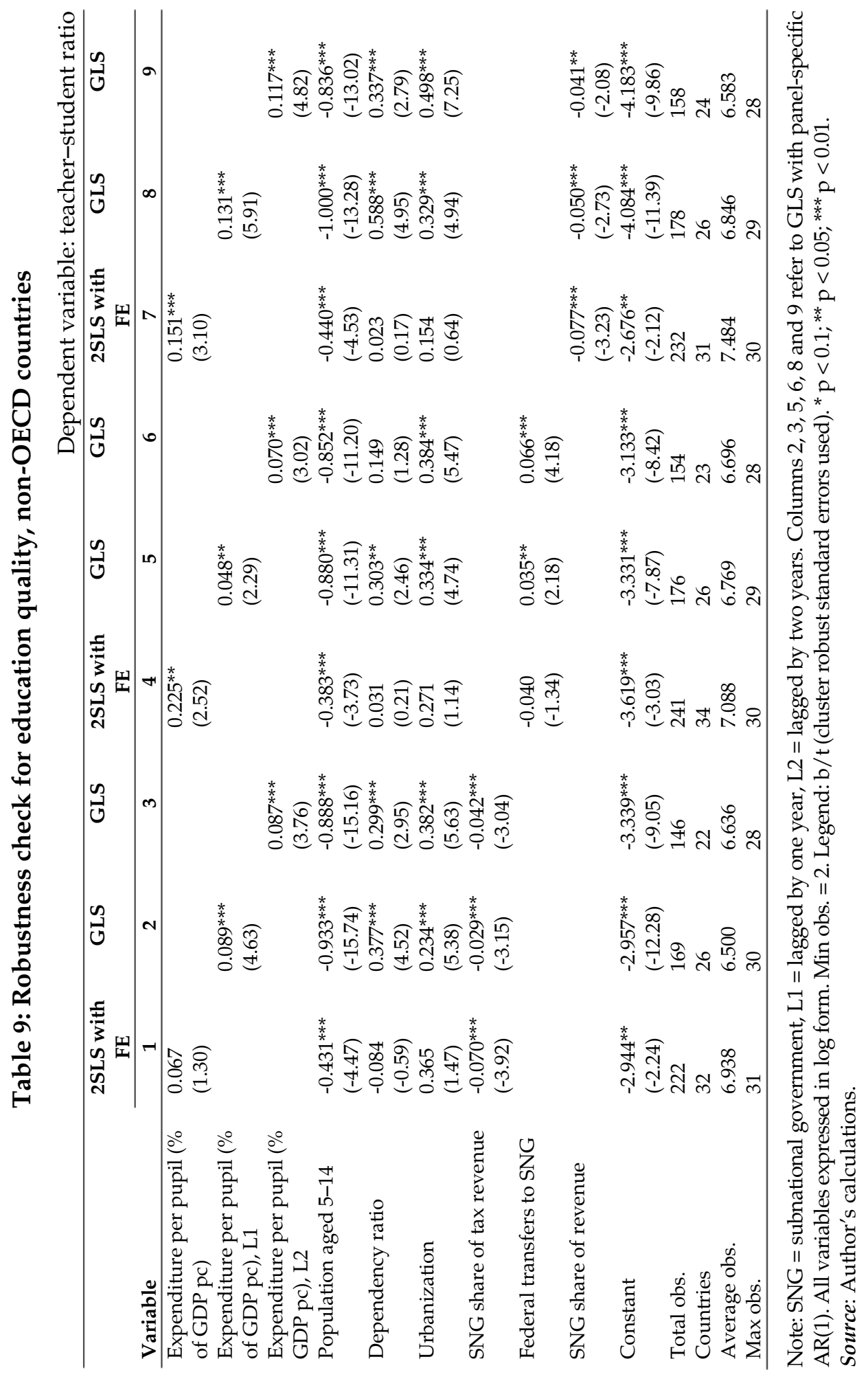


The second measure, subnational total revenues, yields similar results, with greater fiscal decentralization leading to an increase in the number of students per teacher (Table 6). However, the results are insignificant in the baseline regression for the overall sample and for the OECD countries. The weaker GLS estimator produces statistically significant results (Tables 7 and 8), while the 2SLS and IV regression yields a negative and significant coefficient for the non-OECD countries. Again, this suggests that fiscal decentralization results in more students per teacher, causing the teacher-student ratio to suffer (Tables 6 and 9). The coefficients are small, with a 1 percent change in subnational total revenues leading to a 0.06 percent change in the teacher-student ratio in non-OECD countries.

Table 6 also gives the results for federal transfers to the subnational level. Fiscal decentralization appears to have a negative and significant impact on education outcomes. This result is significant for all three datasets, including the OECD countries, which is surprising. One explanation for this is that, in developed countries, local governments receive sector-specific targeted funds. In the education sector, for example, local governments might receive transfers per student. Therefore, the federal transfers variable may be capturing the effect of higher enrollment as local governments have an incentive to improve enrollment rates even in developed countries.

The education expenditure proxy has a positive and statistically significant coefficient across different models of fiscal decentralization and all three datasets. This is as expected, with the results suggesting that higher education spending per pupil improves the quality of education. Education expenditure appears to be universally significant across different estimation techniques. In all three datasets, education spending has significantly higher coefficients in the 2SLS regression relative to the GLS regression (which uses the lagged effect of education spending as an instrument). It is worth noting, however, that using lagged values for per pupil education spending (as a percentage of GDP per capita) causes a loss of almost 100 data points in the overall sample.

A key variable with almost universal significance across different models is urbanization. Urban areas generally provide a better standard of education, with more teachers per student, than rural areas both in OECD and non-OECD countries. This effect is stronger in the latter, implying that there is a greater difference between urban and rural areas in terms of the quality of education. In the regression containing the federal transfers 
variable, the effect of urbanization is driven by the non-OECD countries. Its coefficient remains insignificant for the overall and OECD samples.

Another important determinant of education quality is the proportion of the school-age population. As the latter increases, it puts further pressure on the existing infrastructure. Importantly, this variable also captures school enrollment, suggesting that an increase in the schoolage population will occur regardless of whether these children eventually go to school. Its effect on education quality is difficult to explain because there is greater disparity in the coefficient estimates obtained from the 2SLS and IV model. The coefficients obtained from the GLS and IV estimation are far higher across all three datasets. Instead of focusing on the coefficient, we look at its negative sign, which suggests that a rise in the number of schoolage children leads to higher enrollment and thus lower teaching quality. This is not intuitive in the case of the OECD sample, however.

The dependency ratio is equal to the proportion of dependents (the elderly and children) among the total working-age population. We include this to capture the poverty effect in non-OECD countries (most OECD countries already have social safety nets in place). The variable is significant in the overall and OECD samples, but changes signs between the 2SLS and IV-GLS models (Tables 6 to 8). However, in the case of the non-OECD countries, where the variable matters most, the sign remains consistent, although it is significant only in the IV-GLS model.

Tables 7 to 9 give the results of the IV-GLS estimation, showing that an increase in the dependency ratio has a negative relationship with school enrollment. An increase in poverty, reflected in greater pressure on limited resources, leads to lower enrollment and improves the teacher-student ratio, as the positive coefficient indicates. This suggests that a higher dependency ratio discourages households from sending their children to school rather than shifting them from private to public schools, which would have had the opposite effect as in the case of the OECD sample (Table 6).

\section{Conclusion}

It is important for governments to envisage the short-run and longrun effects of their policies. Short-run efforts normally focus on generating the funds needed to carry out administrative reforms, while long-run efforts are driven by the expected outcome of the policy reform. In this context, education expenditure would ideally capture the short-run effect of fiscal decentralization on education input, the enrollment rate would help gauge 
the education output of decentralization reforms and education quality (as the teacher-student ratio) would measure the outcome. Unfortunately, we could not use the enrollment rate as a dependent variable because the OECD countries, which dominate the sample, have near 100 percent enrollment. The teacher-student ratio is a comprehensive measure of education outcomes and illustrates the government's ability to ensure education quality by providing resources that meet enrollment needs.

This study provides empirical evidence of the distinct effects of different fiscal decentralization policies on the education sector. Thus, different sources of subnational revenue affect education expenditure and quality differently. The most important finding is that, when subnational governments are financed by own-tax revenues, they are more efficient and likely to increase education spending to enhance enrollment. This makes a strong case for localization when self-financed. While the total revenue of the subnational government has a positive effect on education, the sources of financing - for instance, federal transfers - are associated with different results for education spending. This implies that there are political economy issues at stake, such that different policies on decentralization yield different results.

Another key finding is that OECD and non-OECD countries are associated with different results owing to differences in their economic and political structures. The most important distinction is the difference in composition of subnational revenues. The disaggregated results show that local governments have larger self-financed resources in OECD countries. While an increase in federal transfers leads to a rise in education spending in the non-OECD countries, the opposite occurs in OECD countries.

In the case of education quality in the form of the teacher-student ratio, local governments tend to favor student enrollment over maintaining the required number of teachers. This effect is more prominent in the nonOECD countries, most of which are still trying to achieve universal enrollment. Thus, when using a large international panel, it is advisable to identify what drives the results in different regions by disaggregating the datasets. This study shows that decentralized structures address local social needs better. Moreover, governments should institute checks and balances to ensure that federal transfers do not cause inefficiency.

Different policy instruments are used to improve a country's social indicators. Fiscal decentralization is particularly important in relatively less developed countries, many of which have not met their Millennium 
Development Goal targets. This analysis provides evidence that local governments are better able to assess local demands and needs in the education sector, which is encouraging. However, over and above education spending and enrollment, local governments need to focus on improving the quality of education.

While federal transfers might bridge resource shortfalls, they do not carry the same incentives as local resource generation, which makes local governments answerable to their taxpayers. Local governments should, therefore, be encouraged to depend on their own resources. Improved governance, better institutions and local elections can help reduce corruption and inefficiency, such that these resources are then used more effectively.

Treisman (2000) finds that corruption is highly correlated with decentralized structures and thus affects public spending. This makes it important to incorporate this aspect in the analysis and control for the corruption perception index across countries. However, since the data for this indicator is relatively recent and provides only limited coverage, we could not analyze this aspect of decentralization and spending. Future research could examine this in detail. Similarly, other measures such as dropout rates and standardized test scores could also serve as dependent variables to determine the effect of decentralization on the quality of education. Finally, since the equation for public spending is dynamic (a function of the previous period's spending), future research could use the GMM technique to estimate and compare results across a smaller sample (for example, the OECD countries) to avoid the problems associated with unequally spaced, unbalanced panel data. 


\section{References}

Baldacci, E., Clements, B., Gupta, S., \& Cui, Q. (2008). Social spending, human capital and growth in developing countries. World Development, 36(8), 1317-1341.

Baltagi, B. H., \& Wu, P. X. (1999). Unequally spaced panel data regressions with $\mathrm{AR}(1)$ disturbances. Econometric Theory, 15(6), 814-823.

Barankay, I., \& Lockwood, B. (2007). Decentralization and the productive efficiency of government: Evidence from Swiss cantons. Journal of Public Economics, 91(5-6), 1197-1218.

Bardhan, P., \& Mookherjee, D. (2005). Decentralizing antipoverty program delivery in developing countries. Journal of Public Economics, 89(4), 675-704.

Barro, R. J. (1991). Economic growth in a cross-section of countries. Quarterly Journal of Economics, 106(2), 407-443.

Barro, R. J. (1996a). Determinants of economic growth: A cross-country empirical study (Working Paper No. 5698). Cambridge, MA: National Bureau of Economic Research.

Barro, R. J. (1996b). Health and economic growth. Unpublished manuscript, Harvard University, Cambridge, MA.

Barro, R. J., \& Sala-i-Martin, X. (1995). Economic growth. New York: McGraw-Hill.

Behrman, J. R., \& King, E. M. (2001). Household schooling behaviors and decentralization. Economics of Education Review, 20(4), 321-341.

Brueckner, J. K. (2009). Partial fiscal decentralization. Regional Science and Urban Economics, 39(1), 23-32.

Busemeyer, M. R. (2007). Determinants of public education spending in 21 OECD democracies, 1980-2001. Journal of European Public Policy, 14(4), 582-610. 
Chu, K.-Y., Gupta, S., Clements, B., ... Schwartz, G. (1995). Unproductive public expenditures: A pragmatic approach to policy analysis (Pamphlet No. 48). Washington, DC: International Monetary Fund, Fiscal Affairs Department.

Coulombe, S., Tremblay, J.-F., \& Marchand, S. (2004). Literacy scores, human capital and growth across fourteen OECD countries (International Adult Literacy Survey Monograph Series). Ottawa: Statistics Canada.

del Granado, F. J. A., Martinez-Vazquez, J., \& McNab, R. M. (2005). Fiscal decentralization and the functional composition of public expenditures (Working Paper No. 0501). Atlanta, GA: Georgia State University, International Center for Public Policy.

Devine, J. A. (1985). State and state expenditure: Determinants of social investment and social consumption spending in the postwar United States. American Sociological Review, 50(2), 150-165.

Eskeland, G. S., \& Filmer, D. (2007). Autonomy, participation and learning: Findings from Argentine schools and implications for decentralization. Education Economics, 15(1), 103-127.

Faguet, J.-P. (2004). Does decentralization increase government responsiveness to local needs? Evidence from Bolivia. Journal of Public Economics, 88(3-4), 867-893.

Falch, T., \& Fischer, J. A. V. (2012). Public sector decentralization and school performance: International evidence. Economics Letters, 114(3), 276-279.

Fernandez, R., \& Rogerson, R. (2001). The determinants of public education expenditures: Longer-run evidence from the States. Journal of Education Finance, 27(1), 567-583.

Galiani, S., \& Schargrodsky, E. (2002). Evaluating the impact of school decentralization on educational quality [with comments]. Economía, 2(2), 275-314.

Galiani, S., Gertler, P., \& Schargrodsky, E. (2008). School decentralization: Helping the good get better, but leaving the poor behind. Journal of Public Economics, 92(10-11), 2106-2120. 
Gupta, S., Verhoeven, M., \& Tiongson, E. R. (2002). The effectiveness of government spending on education and healthcare in developing and transition economies. European Journal of Political Economy, 18(4), 717-737.

Hanushek, E. A. (2002). Comment [on Galiani and Schargrodsky]: Evaluating the impact of school decentralization on educational quality. Economía, 2(2), 303-305.

Holmes, J. (2003). Measuring the determinants of school completion in Pakistan: Analysis of censoring and selection bias. Economics of Education Review, 22(3), 249-264.

Islam, N. (1995). Growth empirics: A panel data approach. Quarterly Journal of Economics, 110(4), 1127-1170.

Jimenez, E., \& Sawada, Y. (1999). Do community-managed schools work? An evaluation of El Salvador's EDUCO program. World Bank Economic Review, 13(3), 415-441.

Kalirajan, K., \& Otsuka, K. (2012). Fiscal decentralization and development outcomes in India: An exploratory analysis. World Development, 40(8), 1511-1521.

Levine, R., \& Renelt, D. (1992). A sensitivity analysis of cross-country growth regressions. American Economic Review, 82(4), 942-963.

Lucas, R. E. (1988). On the mechanics of economic development. Journal of Monetary Economics, 22(1), 3-42.

Mankiw, N. G., Romer, D., \& Weil, D. N. (1992). A contribution to the empirics of economic growth. Quarterly Journal of Economics, 107(2), 407-437.

Marlow, M. L. (2000). Spending, school structure and public education quality: Evidence from California. Economics of Education Review, 19(1), 89-106.

Miller, C. (1996). Demographics and spending for public education: A test of interest group influence. Economics of Education Review, 15(2), 175-185. 
Musgrave, R. A., \& Musgrave, P. B. (1973). Public finance in theory and practice. New York: McGraw-Hill.

O'Connor, J. (1973). The fiscal crisis of the state. New York: St Martin's Press.

Organisation for Economic Co-operation and Development. (2013). PISA 2012 assessment and analytical framework: Mathematics, reading, science, problem solving and financial literacy. Paris: Author.

Parry, T. R. (1997). Achieving balance in decentralization: A case study of education decentralization in Chile. World Development, 25(2), 211225 .

Psacharopoulos, G. (1994). Returns to investment in education: A global update. World Development, 22(9), 1325-1343.

Rajkumar, A. S., \& Swaroop, V. (2008). Public spending and outcomes: Does governance matter? Journal of Development Economics, 86(1), 96-111.

Romer, P. M. (1986). Increasing returns and long-run growth. Journal of Political Economy, 94(5), 1002-1037.

Sala-i-Martin, X. X. (1997). I just ran two million regressions. American Economic Review, 87(2), 178-183.

Schmidt, S. J., \& McCarty, T. A. (2008). Estimating permanent and transitory income elasticities of education spending from panel data. Journal of Public Economics, 92(10-11), 2132-2145.

Smith, B. D. (1985). Decentralization: The territorial dimension of the state. London: Allen \& Unwin.

Stasavage, D. (2005). Democracy and education spending in Africa. American Journal of Political Science, 49(2), 343-358.

Stegarescu, D. (2004). Public sector decentralization: Measurement concepts and recent international trends (Discussion Paper No. 04-74). Mannheim: Zentrum für Europäische Wirtschaftsforschung.

Tanzi, V., \& Chu, K.-Y. (1998). Income distribution and high-quality growth. Cambridge, MA: MIT Press. 
Treisman, D. (2000). The causes of corruption: A cross-national study. Journal of Public Economics, 76(3), 399-457.

Verbina, I., \& Chowdhury, A. (2004). What determines public education expenditures in Russia? Economics of Transition, 12(3), 489-508.

World Bank. (1995). Priorities and strategies for education: A World Bank review. Washington, DC: Author.

World Bank. (2003). World development report 2003: Sustainable development in a dynamic world: Transforming institutions, growth and quality of life. New York: Oxford University Press.

World Bank. (2012). World development indicators 2012. Washington, DC: Author.

World Bank. (2016). Health nutrition and population statistics. Available from http://data.worldbank.org/data-catalog/health-nutritionand-population-statistics 


\section{Appendix 1}

\section{Determinants of education expenditure, enrollment and effects of fiscal decentralization on education}

Table A1 presents the key variables used to explain different education indicators in the literature. This also helps identify any potential issues that might emerge during estimation. The studies listed draw on different datasets and, therefore, are associated with different potential estimation problems. In explaining different education indicators, the most important variables are per capita income, the proportion of the school-age population, age distribution, demographic characteristics and governance.

In analyzing the link between fiscal decentralization and education, the literature suggests that, when people are equipped to benefit from it, fiscal decentralization has a positive and significant effect on education. However, the effects are not uniform for the poor and nonpoor, which indicates the possibility of elite capture. Thus, when focusing on decentralization, it is equally important to consider policy prerequisites and shortcomings. 


\section{Table A1: Summary of empirical studies on the determinants of education indicators}

\begin{tabular}{|c|c|c|c|}
\hline $\begin{array}{l}\text { Region, period and } \\
\text { estimation technique }\end{array}$ & $\begin{array}{l}\text { Dependent } \\
\text { variable(s) }\end{array}$ & Explanatory variables & Main results \\
\hline \multicolumn{4}{|l|}{ Busemeyer (2007) } \\
\hline $\begin{array}{l}\text { OECD countries, } \\
\text { 1991-2001 } \\
\text { LSDV with panel- } \\
\text { corrected standard } \\
\text { errors }\end{array}$ & $\begin{array}{l}\text { Total public } \\
\text { education spending, } \\
\text { spending on primary } \\
\text { and secondary } \\
\text { education } \\
\text { Spending on tertiary } \\
\text { education (all in } \\
\text { either \% of GDP or } \\
\text { per student) }\end{array}$ & $\begin{array}{l}\text { Significant variables } \\
\text { Fiscal decentralization, } \\
\text { public social spending, } \\
\text { GDP per capita, ratio of } \\
\text { population aged } 65+\text { to } \\
\text { population aged 5-29, } \\
\text { dummies } \\
\text { Broadly insignificant } \\
\text { variables } \\
\text { Nil }\end{array}$ & $\begin{array}{l}\text { Education } \\
\text { expenditures increase } \\
\text { with higher levels of } \\
\text { fiscal } \\
\text { decentralization. } \\
\text { Local governments } \\
\text { compete to provide } \\
\text { better facilities to } \\
\text { attract taxpayers from } \\
\text { other regions. }\end{array}$ \\
\hline
\end{tabular}

Falch and Fischer

(2012)

OECD, unbalanced panel dataset of 25 countries, 1980-2000

Fixed effects model
Student test scores (national average of scores in mathematics and natural science tests)

\section{Significant variables}

Decentralization lagged

(one period), GDP per capita, social spending * decentralization, dummy for OECD PISA test Broadly insignificant variables

Population size, government consumption spending as \% of GDP, government consumption * decentralization, social spending as \% of GDP, social spending * decentralization, primary education spending per pupil as \% of GDP

\begin{tabular}{|c|c|c|c|}
\hline \multicolumn{4}{|c|}{ Verbina and Chowdhury (2004) } \\
\hline $\begin{array}{l}88 \text { regions in the } \\
\text { Russian Federation, } \\
1999 \text { and } 2000 \\
\text { GLS random effects } \\
\text { model }\end{array}$ & $\begin{array}{l}\text { Per capita } \\
\text { expenditure on } \\
\text { education }\end{array}$ & $\begin{array}{l}\text { Significant variables } \\
\text { Total regional revenue, } \\
\text { student-population ratio, } \\
\text { population density, } \\
\text { regional and time } \\
\text { dummies } \\
\text { Broadly insignificant } \\
\text { variables } \\
\text { Nil }\end{array}$ & $\begin{array}{l}\text { Regional revenues } \\
\text { have positive effect } \\
\text { on education } \\
\text { expenditures and } \\
\text { enrolment. Education } \\
\text { is a normal good in } \\
\text { Russia. One } \\
\text { percentage point } \\
\text { increase in average } \\
\text { student-population } \\
\text { ratio increases } \\
\text { education spending } \\
\text { by } 0.5 \text { percentage } \\
\text { point. }\end{array}$ \\
\hline
\end{tabular}




\begin{tabular}{|c|c|c|c|}
\hline $\begin{array}{l}\text { Region, period and } \\
\text { estimation technique }\end{array}$ & $\begin{array}{l}\text { Dependent } \\
\text { variable(s) }\end{array}$ & Explanatory variables & Main results \\
\hline $\begin{array}{l}\text { Africa, unbalanced } \\
\text { panel of } 44 \text { countries, } \\
\text { 1980-96 } \\
\text { OLS, fixed effects } \\
\text { model }\end{array}$ & $\begin{array}{l}\text { Total public spending } \\
\text { on overall education } \\
\text { Public spending on } \\
\text { primary education }\end{array}$ & $\begin{array}{l}\text { Significant variables } \\
\text { Real GDP per capita, } \\
\text { multiparty competition, } \\
\text { foreign aid as \% of GDP, \% } \\
\text { of rural and urban } \\
\text { population under } 15 \\
\text { Broadly insignificant } \\
\text { variables } \\
\text { Election years }\end{array}$ & $\begin{array}{l}\text { Multiparty } \\
\text { competition and GDP } \\
\text { per capita have } \\
\text { positive effects on } \\
\text { education spending. } \\
\text { Foreign aid has } \\
\text { negative impact on } \\
\text { education spending. }\end{array}$ \\
\hline
\end{tabular}

Gupta, Verhoeven and Tiongson (2002)

Cross-sectional data Educational

for 45 developing and attainment (gross

transitional countries, enrolment rate) in (i)

1993-94

OLS and 2SLS primary and secondary education and (ii) secondary education

Persistence to Grade 4

Dropout rate at the primary level

\section{Significant variables}

Ratio of public spending

on education to GDP, spending on primary and secondary education as share of total education spending, per capita GDP (in PPP terms), share of population aged 0-14, urbanization, child nutrition (proxy = child mortality), dummy variables for regions Broadly insignificant variables Differ across models and estimation techniques
Public spending on education is associated with improvements in access to and attainment of education. Five percentage point increase in government spending on primary and secondary education yields more than 1 percentage point rise in gross secondary enrolment.

Rajkumar and Swaroop (2008)

57 countries, annual data for 1990, 1997 and 2003

OLS and 2SLS (with random effects)

Education
failure/nonattainmen
t: proportion of those
who failed to
complete adequate
level of primary
schooling

Education

Significant variables

Per capita GDP (in PPP

terms), income inequality, dummy for East Asia, interaction terms (index of corruption * share of public primary education spending in GDP, quality of bureaucracy * share of public primary education spending in GDP)

Broadly insignificant variables Share of public primary education spending in GDP, adult illiteracy rate, measures of governance (index of corruption or quality of bureaucracy), income inequality, predominantly Muslim, ethno-linguistic fractionalization, urbanization, population aged 6-12, dummy for 1997 and 2003
In the absence of good governance, public spending loses its effectiveness. Public spending increases primary educational attainment in countries with good governance, but has virtually no impact on education outcomes in countries that suffer from poor governance. 


\begin{tabular}{|c|c|c|c|}
\hline $\begin{array}{l}\text { Region, period and } \\
\text { estimation technique }\end{array}$ & $\begin{array}{l}\text { Dependent } \\
\text { variable(s) }\end{array}$ & Explanatory variables & Main results \\
\hline \multicolumn{4}{|l|}{ Holmes (2003) } \\
\hline $\begin{array}{l}\text { Pakistan, primary } \\
\text { data from the } \\
\text { Pakistan Integrated } \\
\text { Household Survey } \\
\text { for } 1991 \\
\text { Censored ordered } \\
\text { probit analysis }\end{array}$ & $\begin{array}{l}\text { Years of schooling for } \\
\text { children aged 5-25, } \\
\text { by gender }\end{array}$ & $\begin{array}{l}\text { Significant variables } \\
\text { Age, age squared, } \\
\text { mother's education, } \\
\text { father's education, value of } \\
\text { land and } \\
\text { property /100,000, Muslim, } \\
\text { rural, sewage facilities, } \\
\text { distance to middle and } \\
\text { secondary schools, average } \\
\text { female wage, average male } \\
\text { wage, dummies for } \\
\text { Balochistan and NWFP } \\
\text { Broadly insignificant } \\
\text { variables } \\
\text { Distance to primary } \\
\text { school, dummy for Sindh }\end{array}$ & $\begin{array}{l}\text { Parental education is } \\
\text { an important } \\
\text { determinant of } \\
\text { schooling demand. } \\
\text { Boys' schooling is } \\
\text { affected more by } \\
\text { paternal education } \\
\text { while maternal } \\
\text { education increases } \\
\text { schooling demand for } \\
\text { girls. Household } \\
\text { wealth and average } \\
\text { male wage has } \\
\text { positive effect on } \\
\text { educational } \\
\text { attainment. } \\
\text { Deficiency in basic } \\
\text { facilities (sewage) } \\
\text { and distance to } \\
\text { school have negative } \\
\text { effect on schooling } \\
\text { demand. }\end{array}$ \\
\hline
\end{tabular}

Schmidt and McCarty (2008)

48 US states, panel data, 1980-2000

OLS, fixed effects, random effects and nonlinear least squares
State and local education spending per capita
Significant variables

State per capita income, derived future income, student fraction of state population (617), demographic characteristics (fraction of state population that is: high school-educated, below poverty line, over 64 , living in urban areas, and ethnically Asian or Caucasian)

Broadly insignificant variables Federal aid for education, general (unrestricted) federal aid, reform dummy (court-ordered reform of state's education finance system), fraction of state population that is college-educated
Fernandez and Rogerson (2001)
48 US states, panel for Real per student 1950-90 level and first difference
OLS with data in current expenditure on public primary and secondary education

$\begin{array}{ll}\text { Significant variables } & \text { Two major } \\ \text { Real personal income, } & \text { determinants of } \\ \text { number of students in } & \text { public education } \\ \text { average daily attendance, } & \text { spending are } \\ \text { population over 65 } & \text { personal income and } \\ \text { Broadly insignificant variables } & \text { number of students in } \\ \text { Population of school age } & \text { average daily } \\ (5-17) & \text { attendance. }\end{array}$

Future income has important bearing on the state's current expenditures. Current education spending is not influenced by present or past aid.

,

\author{
Parental education is \\ an important \\ schooling demand. \\ Bffected more by \\ paternal education \\ education increases \\ girls. Household \\ wealth and average \\ positive effect on \\ educational \\ Deficiency in basic \\ effect on schooling
}




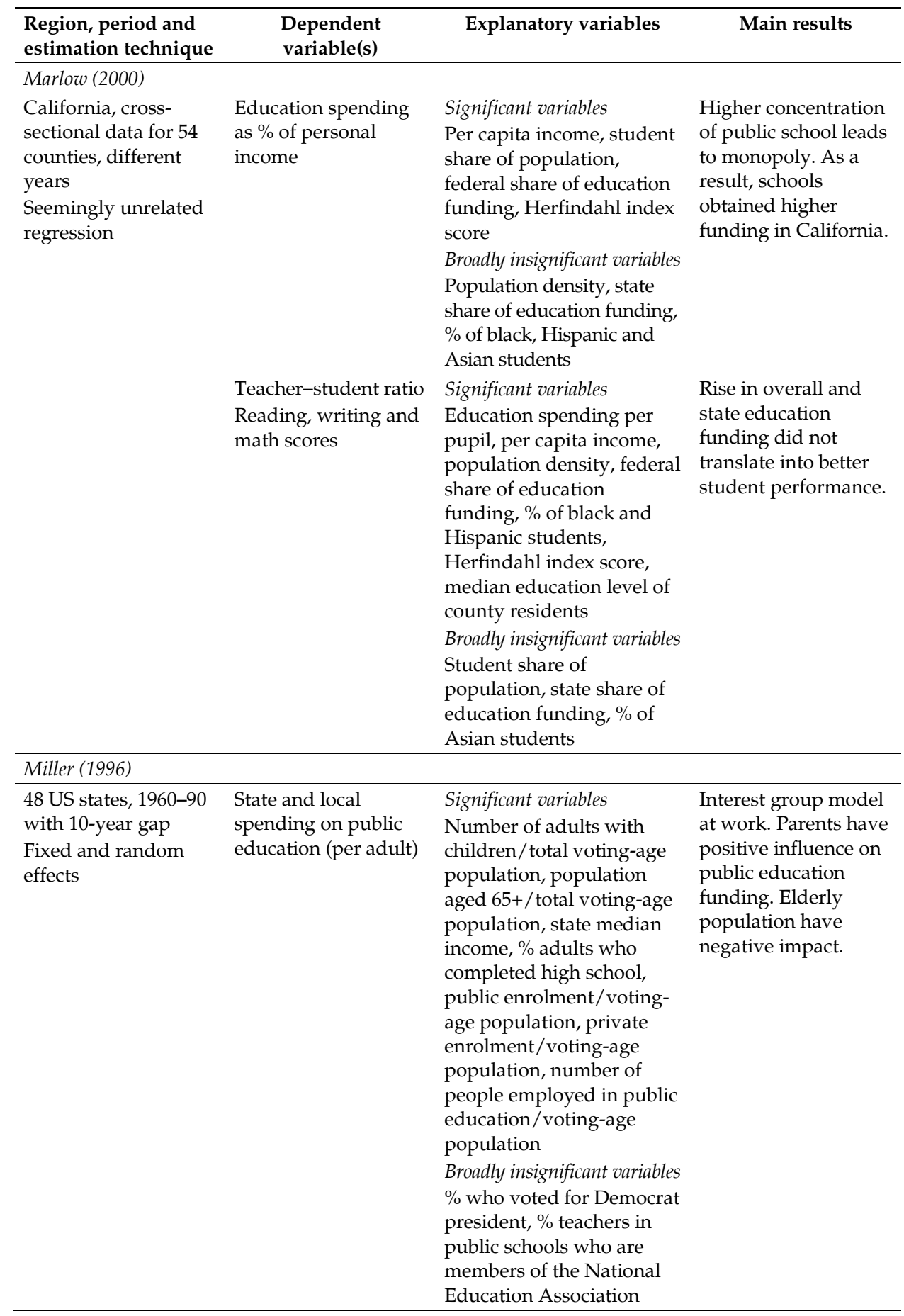




\section{Appendix 2}

\section{A note on the construction of fiscal decentralization measures}

This study is based on recent panel data for 78 developed and developing countries. The dataset it uses was released by the World Bank in October $2012^{11}$ and is derived from the International Monetary Fund's Government Finance Statistics. These provide detailed information on revenues and expenditures for the three tiers of government and thus reflect the fiscal and administrative arrangements of each country (see World Bank, 2012). The dataset on fiscal decentralization indicators provides data for the period 1972-2010 (although with gaps) ${ }^{12}$ and covers all the important definitions of fiscal decentralization employed in the literature. This study adopts the revenue approach and analyzes different fiscal decentralization indicators related to subnational revenues. ${ }^{13}$

The World Bank dataset uses two different accounting methods: accrual and cash. Historically, the Government Finance Statistics were recorded using the cash accounting method where the time assigned to flows is when cash is received or disbursed. Since 2001, many countries have switched to the accrual accounting method and report data on an accrual basis, where the time assigned to flows is when they were created. Nevertheless, the shift from the cash to the accrual method is noticeable among developing countries that either continue to report data on a cash basis or that shifted to the accrual method later. Given the difference in definitions (how the money disbursed is recorded in a certain year), there is a slight difference between the figures obtained from either method and the data cannot be readily combined into one series.

The number of observations for the fiscal decentralization data varies by accounting method. Figures obtained on an accrual basis generally start from 1999/2000 and continue to date, while historical figures are reported using the cash accounting method. There is some overlap around 2000, with figures reported in both series, but this is not always the case. Moreover, for some countries, the figures reported in both series are close together, while for others they diverge considerably.

\footnotetext{
${ }^{11}$ The previous dataset covered fewer countries, with observations available only till 2001.

${ }^{12}$ Although the data used in this study is unbalanced and has missing values, we have not created imputed values for the missing observations because this can lead to measurement errors.

13 We avoid the expenditure approach to fiscal decentralization measures, which tends to overestimate the authority of subnational governments and thus overstate the degree of fiscal decentralization.
} 
To combine the two series, we analyze the data for each country separately and then decide on a consistent method. To avoid any loss of data, we combine both series not only to increase the number of observations, but also to minimize the chances of potential sample selection bias. This is important because data reporting on an accrual basis presumably indicates the developed nature of the country. Countries with better accounting systems shifted to the accrual accounting method more quickly. Combining the two series for each fiscal decentralization measure yields four different scenarios:

- Data reported solely on a cash basis: the same values are retained in the combined series without being treated.

- Data reported solely on an accrual basis: the same values are retained in the combined series without being treated because the accounting method itself cannot affect the volume of resources available at the subnational level. The only difference in the two methods lies in the recording time of the transaction. Therefore, by default, the two series should report a similar trend over the long run.

- Data reported using both the cash and accrual methods, with overlap: both series are spliced together by converting the accrual series to a cash base. ${ }^{14}$

- Data reported using both the cash and accrual methods, with no overlap and figures in both series next to each other in consecutive years. For example, data on subnational tax revenues for the US was reported on a cash basis till 2001 and on an accrual basis thereafter. The accrual series is then extended backward by one year, assuming the same value for the previous year to create an overlap. Accordingly, the two series are spliced together.

Tables A2-A5 describe the data available. The cash series has more observation points, but the accrual series provides the most recent data for the last ten years. Tables A2 and A3 give the summary statistics for the combined series of fiscal decentralization measures and present a disaggregated form of the available data for OECD and non-OECD

14 The data splicing is carried out in a manner similar to changing the base year for a GDP series. Once an overlap between the two series for each year is obtained, we find the first available data point in the accrual data series and divide it by the last available cash series figure for the same year. This provides a unique multiplying factor for each variable series, which is then multiplied by the given accrual data series for each country to convert the figures to a cash accounting base. Having converted both series to the same base, a combined series for each fiscal decentralization measure is produced that has a cash accounting base. 
countries. This bifurcation highlights the availability of data for the variables used (fiscal decentralization proxies). The OECD countries are more decentralized, based on the suggested proxies. We combine the series because a large number of observations is available for both the accrual and cash series and it would be inefficient to lose data reported in either.

\section{Table A2: Descriptive statistics for fiscal decentralization measures, OECD countries}

\begin{tabular}{|c|c|c|c|c|c|c|}
\hline \multicolumn{2}{|l|}{ Variable } & Mean & SD & Min & Max & Observations \\
\hline \multirow{4}{*}{$\begin{array}{l}\text { Accrual method } \\
\text { Subnational govt. share of tax } \\
\text { revenue }\end{array}$} & & & & & & \\
\hline & Overall & 30.48 & 12.23 & 1.37 & 57.76 & $\mathrm{~N}=247$ \\
\hline & Between & & 14.69 & 1.52 & 56.35 & $\mathrm{n}=25$ \\
\hline & Within & & 2.20 & 21.92 & 40.04 & T-bar $=9.88$ \\
\hline \multirow{3}{*}{$\begin{array}{l}\text { Vertical grants as share of } \\
\text { subnational govt. revenue }\end{array}$} & Overall & 41.17 & 18.88 & 8.51 & 79.67 & $\mathrm{~N}=247$ \\
\hline & Between & & 18.64 & 9.33 & 75.02 & $\mathrm{n}=25$ \\
\hline & Within & & 4.85 & 26.22 & 58.79 & $\mathrm{~T}$-bar $=9.88$ \\
\hline \multirow{3}{*}{$\begin{array}{l}\text { Subnational govt. share of } \\
\text { revenue }\end{array}$} & Overall & 31.56 & 11.95 & 1.37 & 57.76 & $N=201$ \\
\hline & Between & & 14.69 & 1.52 & 54.28 & $\mathrm{n}=23$ \\
\hline & With & & 1.48 & 27.45 & 38.37 & $\mathrm{~T}$-bar $=8.74$ \\
\hline \multirow{4}{*}{$\begin{array}{l}\text { Cash method } \\
\text { Subnational govt. share of tax } \\
\text { revenue }\end{array}$} & & & & & & \\
\hline & Overall & 20.82 & 14.45 & 1.29 & 58.74 & $N=326$ \\
\hline & Between & & 15.30 & 4.21 & 54.84 & $\mathrm{n}=22$ \\
\hline & Within & & 2.42 & 12.51 & 28.13 & T-bar \\
\hline \multirow{3}{*}{$\begin{array}{l}\text { Vertical grants as share of } \\
\text { subnational govt. revenue }\end{array}$} & Overall & 43.94 & 18.33 & 9.54 & 86.66 & $N=298$ \\
\hline & Between & & 18.43 & 10.94 & 79.49 & $\mathrm{n}=23$ \\
\hline & Within & & 5.86 & 18.05 & 74.71 & $\mathrm{~T}$-bar $=12.96$ \\
\hline \multirow{3}{*}{$\begin{array}{l}\text { Subnational govt. share of } \\
\text { revenue }\end{array}$} & Overall & 29.39 & 12.14 & 1.70 & 57.21 & $N=295$ \\
\hline & Between & & 13.91 & 1.80 & 51.99 & $\mathrm{n}=24$ \\
\hline & Within & & 2.65 & 12.47 & 37.99 & T-bar $=12.29$ \\
\hline \multirow{4}{*}{$\begin{array}{l}\text { Combined series } \\
\text { Subnational govt. share of tax } \\
\text { revenue }\end{array}$} & & & & & & \\
\hline & Overall & 20.67 & 14.37 & 0.80 & 58.74 & $N=538$ \\
\hline & Between & & 16.14 & 1.61 & 54.84 & $\mathrm{n}=27$ \\
\hline & Within & & 3.09 & 5.69 & 36.00 & T-bar $=19.92$ \\
\hline \multirow{3}{*}{$\begin{array}{l}\text { Vertical grants as share of } \\
\text { subnational govt. revenue }\end{array}$} & Overall & 43.57 & 18.94 & 8.51 & 90.56 & $N=503$ \\
\hline & Between & & 17.75 & 9.83 & 77.51 & $\mathrm{n}=27$ \\
\hline & Within & & 6.49 & 20.32 & 70.41 & $\mathrm{~T}-$ bar $=18.63$ \\
\hline \multirow{3}{*}{$\begin{array}{l}\text { Subnational govt. share of } \\
\text { revenue }\end{array}$} & Overall & 29.48 & 12.08 & 5.40 & 57.76 & $\mathrm{~N}=451$ \\
\hline & Between & & 13.91 & 5.53 & 54.28 & $\mathrm{n}=26$ \\
\hline & Within & & 2.52 & 12.56 & 38.08 & $\mathrm{~T}$-bar $=17.35$ \\
\hline
\end{tabular}

Source: Author's calculations. 


\section{Table A3: Descriptive statistics for fiscal decentralization measures, non-OECD countries}

\begin{tabular}{|c|c|c|c|c|c|c|}
\hline \multicolumn{2}{|l|}{ Variable } & Mean & SD & Min & $\operatorname{Max}$ & Observations \\
\hline \multicolumn{7}{|l|}{ Accrual method } \\
\hline \multirow{3}{*}{$\begin{array}{l}\text { Subnational govt. share of tax } \\
\text { revenue }\end{array}$} & Overall & 20.22 & 11.75 & 1.03 & 47.11 & $\mathrm{~N}=97$ \\
\hline & Between & & 13.74 & 1.08 & 45.82 & $\mathrm{n}=17$ \\
\hline & Within & & 1.65 & 14.90 & 24.60 & $\mathrm{~T}$-bar $=5.71$ \\
\hline \multirow{3}{*}{$\begin{array}{l}\text { Vertical grants as share of } \\
\text { subnational govt. revenue }\end{array}$} & Overall & 46.64 & 14.88 & 8.26 & 78.00 & $N=95$ \\
\hline & Between & & 16.96 & 9.56 & 78.00 & $\mathrm{n}=15$ \\
\hline & Within & & 4.31 & 31.19 & 57.78 & $\mathrm{~T}-\mathrm{bar}=6.33$ \\
\hline \multirow{3}{*}{$\begin{array}{l}\text { Subnational govt. share of } \\
\text { revenue }\end{array}$} & Overall & 24.07 & 18.71 & 1.57 & 98.27 & $N=96$ \\
\hline & Between & & 17.72 & 1.70 & 68.79 & $\mathrm{n}=15$ \\
\hline & Within & & 9.21 & -14.80 & 53.55 & $\mathrm{~T}-\mathrm{bar}=6.4$ \\
\hline \multicolumn{7}{|l|}{ Cash method } \\
\hline \multirow{3}{*}{$\begin{array}{l}\text { Subnational govt. share of tax } \\
\text { revenue }\end{array}$} & Overall & 11.38 & 10.60 & 0.16 & 48.13 & $\mathrm{~N}=213$ \\
\hline & Between & & 11.98 & 0.18 & 47.55 & $\mathrm{n}=37$ \\
\hline & Within & & 1.90 & 5.48 & 19.39 & $\mathrm{~T}-\mathrm{bar}=5.76$ \\
\hline \multirow{3}{*}{$\begin{array}{l}\text { Vertical grants as share of } \\
\text { subnational govt. revenue }\end{array}$} & Overall & 46.22 & 23.09 & 1.39 & 92.72 & $\mathrm{~N}=232$ \\
\hline & Between & & 23.34 & 4.04 & 87.51 & $\mathrm{n}=40$ \\
\hline & Within & & 10.60 & 18.59 & 76.31 & $\mathrm{~T}$-bar $=5.8$ \\
\hline \multirow{3}{*}{$\begin{array}{l}\text { Subnational govt. share of } \\
\text { revenue }\end{array}$} & Overall & 17.93 & 11.35 & 0.82 & 48.96 & $N=216$ \\
\hline & Between & & 13.07 & 0.82 & 47.83 & $\mathrm{n}=36$ \\
\hline & Within & & 2.86 & 8.90 & 31.13 & T-bar $=6$ \\
\hline \multicolumn{7}{|l|}{ Combined series } \\
\hline \multirow{3}{*}{$\begin{array}{l}\text { Subnational govt. share of tax } \\
\text { revenue }\end{array}$} & Overall & 13.05 & 11.32 & 0.16 & 48.13 & $\mathrm{~N}=286$ \\
\hline & Between & & 12.13 & 0.18 & 46.75 & $\mathrm{n}=42$ \\
\hline & Within & & 2.25 & -3.97 & 22.29 & $\mathrm{~T}-\mathrm{bar}=6.81$ \\
\hline \multirow{3}{*}{$\begin{array}{l}\text { Vertical grants as share of } \\
\text { subnational govt. revenue }\end{array}$} & Overall & 45.72 & 21.85 & 1.39 & 92.72 & $\mathrm{~N}=308$ \\
\hline & Between & & 22.49 & 4.04 & 87.51 & $\mathrm{n}=45$ \\
\hline & Within & & 9.92 & 18.09 & 77.30 & $\mathrm{~T}-\mathrm{bar}=6.84$ \\
\hline \multirow{3}{*}{$\begin{array}{l}\text { Subnational govt. share of } \\
\text { revenue }\end{array}$} & Overall & 19.86 & 14.51 & 0.82 & 98.27 & $N=295$ \\
\hline & Between & & 14.72 & 0.82 & 68.79 & $\mathrm{n}=40$ \\
\hline & Within & & 5.82 & -19.00 & 49.35 & $\mathrm{~T}-\mathrm{bar}=7.37$ \\
\hline
\end{tabular}

Source: Author's calculations. 
Table A4: List of countries and maximum data points for any estimation

\begin{tabular}{ll|lll}
\hline OECD countries (observations) & \multicolumn{3}{|c}{ Non-OECD countries } \\
\hline Australia (16) & Japan (5) & Argentina (7) & Georgia (1) & Nicaragua (1) \\
Austria (35) & Luxembourg & Armenia (3) & Guatemala (1) & Pakistan (16) \\
Belgium (23) & $(20)$ & Azerbaijan (2) & Honduras (1) & Panama (1) \\
Denmark (29) & Malta (4) & Belarus (1) & Hungary (27) & Paraguay (1) \\
Finland (34) & Netherlands & Bolivia (7) & India (8) & Peru (11) \\
France (36) & $(32)$ & Botswana (1) & Iran (9) & Poland (8) \\
Germany (5) & New Zealand & Brazil (3) & Jamaica (2) & Romania (5) \\
Greece (2) & (14) & Bulgaria (9) & Jordan (1) & Senegal (2) \\
Iceland (16) & Norway (33) & Cape Verde (2) & Kenya (1) & Serbia (3) \\
Ireland (35) & Portugal (29) & Chile (19) & Korea, Rep. (4) & Slovak Rep. (13) \\
Israel (32) & Spain (28) & China (3) & Latvia (11) & Slovenia (7) \\
Italy (14) & Sweden (21) & Colombia (7) & Lesotho (3) & South Africa \\
& Switzerland & Congo, Rep. (2) & Lithuania (7) & (11) \\
& (18) & Costa Rica (4) & Malaysia (8) & Swaziland (3) \\
& UK (31) & Cyprus (3) & Mauritius (9) & Thailand (28) \\
& US (17) & Czech Rep. (16) & Mexico (9) & Tunisia (1) \\
& & Dominican & Moldova (4) & Uganda (3) \\
& & Republic (1) & Morocco (7) & Zambia (2) \\
& & El Salvador (6) & & \\
\hline
\end{tabular}

Table A5: List of countries that joined OECD later

\begin{tabular}{llcccc}
\hline No. & Country & Data starts & Data till & $\begin{array}{c}\text { Maximum } \\
\text { observations }\end{array}$ & Joined OECD \\
\hline 1 & Czech Rep. & 1993 & 2009 & 16 & 1995 \\
2 & Korea & 2006 & 2009 & 4 & 1996 \\
3 & Poland & 2002 & 2009 & 8 & 1996 \\
4 & Chile & 1974 & 2009 & 19 & 2010 \\
5 & Estonia & 1997 & 2008 & 10 & 2010 \\
6 & Slovenia & 1992 & 2003 & 7 & 2010 \\
7 & Israel & 1974 & 2009 & 32 & 2010 \\
8 & Hungary & 1981 & 2009 & 27 & 1996 \\
9 & Mexico & 1989 & 2000 & 9 & 1994 \\
10 & Slovak Rep. & 1996 & 2009 & 13 & 2000 \\
\hline
\end{tabular}

Note: For the study's purposes, countries 1-3 are considered OECD countries because the bulk of the data was collected after they had joined the OECD. Countries 4-7 are considered non-OECD countries because the data was collected before they joined the OECD. Countries 8-10 are considered non-OECD countries because, although the year they joined the OECD falls within the data collection period, on average they had a similar number of observations falling before and after that year. Dividing a single country's data into two parts would have led to double counting. 